\title{
TEMAS RELIGIOSOS EN LA PINTURA VASCULAR TARTÉSICA E IBERA Y SUS PROTOTIPOS DEL PRÓXIMO ORIENTE FENICIO
}

J.M. BLÁZQUEZ

\begin{abstract}
Se pasa revista a una serie de motivos iconográficos representados en vasos de procedencia tartésica e ibérica, se estudia su significado y se les pone en relación con temas similares del Próximo Oriente.
\end{abstract}

The author studies the signification of series of iconographic motives found in vases of tartesic and iberic origin, and relates them to similar themes in the Ancient Near East.

En la actualidad es posible conocer mejor las pinturas vascular tartésicas e iberas y sus prototipos del Próximo Oriente fenicio. El tema fue tratado, centrándose en la pintura vascular ibérica, hace ya muchos años, por uno de los mejores hispanistas, hoy injustamente olvidado, el profesor de la Universidad de Bonn E. Kukahn (KUKAHN, 1962) y por uno de los mejores conocedores del mundo ibérico, $R$. Ramos (RAMOS, 1991; GONZÁLEZ, 1997), director del Museo Arqueológico Municipal de Elche. Hoy en día es posible profundizar más y aportar un número mayor de paralelos al tema, debido al nuevo material aparecido dentro de la Península Ibérica, mucho mejor publicado y conocido que hace años, entre los que hay que destacar por su carácter fundamental y por ampliar mucho el horizonte del tema, la publicación de M. Belén y de sus compañeros sobre el santuario fenicio de Carmona (Sevilla), que ellos excavaron, así como las cerámicas halladas en Lora del Río (Sevilla) publicadas por J. Remesal. Lo mismo que sucede con el material procedente del Próximo Oriente que además de aumentar ha sido mucho mejor estudiado. Reforzar la tesis presentada es lo que pretende este trabajo.

\section{SANTUARIO DE CARMONA (SEVILLA)}

\section{Fila de Grifos}

El santuario fenicio de Carmona se encuentra enclavado en la casa-palacio del Mar- qués de Saltillo (BELÉN y otros, 1998). Estamos de acuerdo con los excavadores en que se trata de un santuario de tipo fenicio, de los varios que estaban abiertos al culto en Turdetania, entre ellos Cástulo'.

Posiblemente los devotos, que visitaban este lugar sagrado, eran fenicios asentados en una de las ricas vegas que abundaban en el sur de España ${ }^{2}$; fenicios que llegaron huyendo de la presión asiria en Siria, en Fenicia y en Palestina, representada gráficamente en los relieves asirios.

La presión asiria fue constante. Ya Teglatfalasar I (1114-1076 a.C.) intentó controlar Siria y Líbano y recibió tributos de Biblos, de Sidón y de Arvad. El poder asirio alcanzó su cumbre en el Imperio Nuevo (912-609 a.C.) cuando, al menos de un modo temporal, controló Siria y las regiones orientales de Asia Menor. Asiria deportaba a las poblaciones vencidas y las sustituía por otras.

Asurnasirpal II (883-859 a.C.) menciona en las inscripciones sus campañas en Karkemis

\footnotetext{
'BLÁZQUEZ 1975a, 148-162; BLÁZQUEZ 1992, passim; BLÁZQUEZ 1991, 348-354; BLÁZQUEZ y VALIENTE 1981; BLÁZQUEZ, GARCÍA-GELABERT y LÓPEZ PARDO 1985.

${ }^{2}$ AUBET 1985; AUBET 1994; ALVAR y BLÁZQUEZ 1993a. La bibliografía menuda BLÁQUEZ 1975; BLÁZQUEZ 1980; BLÁZQUEZ 1989, 31-78; BLÁZQUEZ 1993a; MALUQUER 1969; AAVV 1986; NIEMEYER 1982; AAVV s/a; DEL OLMO LETE y AUBET 1986; RUIZ MATA, SCHUBART y ARTEAGA 1994, 379-470; CORZO 1989, 94-158; WAGNER 1983; BLÁZQUEZ, ALVAR y WAGNER 1999; AAVV 2000; MATTÍN RUIZ 1995. En general KRINGS 1995; MOSCATI 1988.
} 
y en el Líbano, llegando al Mediterráneo. Cada año hizo una expedición hasta el oeste de su reino. Es el primer monarca asirio que entró en contacto con Israel. Ajab de Israel (869-850 a.C.) intervino en la coalición contra Asiria y lucho junto al ejército sirio en Carcar, 853 a.C. En 841, cuando los asirios cercaban Damasco, Jehú le envió un tributo citado en el obelisco negro de Salmanasar III; Adadninari III (810783 a.C.) luchó contra Siria y Palestina. Recibió tributos de Palestina. Teglatfalaser III reconquistó Siria. Recibió tributos de Ajab, rey de Judá (735-738 a.C.) y de Menejen (745-738 a.C.), rey de Israel. En 738 a.C. el monarca asirio impuso una contribución de 50 siclos a 60.000 terratenientes de Israel. Venció el monarca asirio a Pecaj, rey de Israel (737-732 a.C.) según la documentación asiria e instaló en el trono de Israel a Oseas (732-724 a.C.), que fue el último monarca. Por sugerencia de Ajab de Juda (2Re 16, 10-11) quitó a Israel las provincias de Megiddo y de Galaad.

Salmanasar V (727-722 a.C.) conquistó Siquem y cercó Tiro y Samaría (2Re 17. 3-6; 18. 9-10). Sargón II (721-705 a.C.) derrotó a Tiro. Su comandante en jefe (/s. 20.1) estuvo presente en Asdod. En 711 a.C. Iuchó con éxito contra las ciudades filisteas. Asentó extranjeros en Samaría, que había caído en 722 a.C. Sargón II deportó 22.290 israelitas a Mesopotamia Superior y a Media.

Senaquerib dirigió la tercera campaña contra Fenicia, Filistea y Judá. Realizó una campaña contra Jerusalén en 701 (2Re 18.1416) reinando Ezequías (715-687 a.C.). Saqueó buen número de ciudades y deportó muchos judíos. Asarjaddón (681-669 a.C.) se relaciona con una deportación (Esd. 4.2). Recibió tributo de Manases, rey de Judá. En 677 a.C., destruyó Sidón

Josías de Judá reclamó las provincias de Samaría, Galaad y Galilea ya en tiempos de la decadencia asiria.

Bajo el poder de Babilonia la presión sobre Siria, Fenicia y Palestina continuó igual. Después de Karkemis y la victoria de Samen contra el ejército egipcio, Nabucodonosor de Babilonia controló toda Siria y Palestina $(\mathrm{Jr}$. 46.2-6). En el año 597 a.C., cayó Jerusalén en poder del monarca babilónico (2Re 24.6-15; $2 \mathrm{Cr}$ 36.9-10). El rey Joaquim de Judá (598-597 a.C.) fue deportado a Babilonia con los nobles y cierto número de ciudadanos. En $588 \mathrm{Nabu-}$ codonosor se vio obligado a sitiar por segunda vez Jerusalén, pues el rey de Judá, Sedecías, (597-587 a.C.) quiso sacudirse el yugo de
Babilonia. Jerusalén fue tomada en 587 ( $2 R e$ 25.1-2; 2Cr 36.11-14; Jr39.1-7). La ciudad fue saqueada, el rey de Judá cegado y deportado cargado de cadenas a Babilonia.

Todos estos acontecimientos, que tienen por escenario Siria, Fenicia y Palestina, explican satisfactoriamente la colonización fenicia y siria de Occidente.

Desde muchos siglos antes, los monarcas de las ciudades-estado del interior del Creciente Fértil habían tenido la tendencia a conquistar el Líbano, por su riqueza en maderas y a llegar al Mediterráneo como el soberano acadio Sargón (2334-2279 a.C.), Naramsin (2254-2218 a.C.), Ennannatum de Lagas (24292405 a.C.) y Gudea, Príncipe de Lagas (2200 a.C.). Estos dos últimos importaban madera del Líbano y los dos primeros lo conquistaron. Las fuentes neosumerias de la III dinastía de Ur (2112-2004 a.C.) se refieren al control del país donde talaban los cedros.

Esta presión ha quedado gráficamente bien representada en los relieves asirios: batalla con infantería y carros ante una ciudad y asalto con arietes a la muralla ${ }^{3}$; entrega de tributos de Tiro ${ }^{4}$ s. IX a.C.; saco de Hamaan (FRANKFORT 1970, f. 172) y capitulación de la ciudad de Laquis en Judea (FRANKFORT 1970, f. 166) ante Senaquerib en 700 a.C.

Interesa al contenido de este trabajo las pinturas de varios pithoi de Carmona, depositados como material votivo en el santuario, ya ellos o su contenido. La cronología del yacimiento va de la segunda mitad del siglo VII a los comienzos del s. V a.C.

Los pithoi depositados eran tres. La zona central del llamado por los excavadores pithos A va decorada con un friso de cuatro grifos (fig. 1) alados, con falderín entre las patas delanteras, que marchan de perfil, de derecha a izquierda, entre flores y capullos de loto. La cabeza es pequeña, todos caminan de perfil, el pico es doblado y puntiagudo, el cuello esbelto y el rabo de bóvido levantado con la punta doblada. Posiblemente, el artesano quiso representar grifos y no un simple ser fantástico (BE-

\footnotetext{
${ }^{3}$ FRANKFORT 1970, f. 147; AMIET 1980, ff. 107-108 s. IX a.C

${ }^{4}$ FRANKFORT 1970, f. 156; AMIET 1980, ff. 614, 616, 617. También el famoso obelisco de Salmanasar III con la sumisión de Jehu de Israel y la aceptación de su tributo y de otros en cuatro paneles, AMIET 1980, 105, f. 157 y f. 593 con la entrega del botín de una ciudad conquistada por Tigalpileser III; f. 167 con el asalto de una ciudad por el ejército de Senaquerib; ff. 170-171 con la derrota de los elamitas. Es fundamental HERZOG y GICHON 1997, passim.
} 


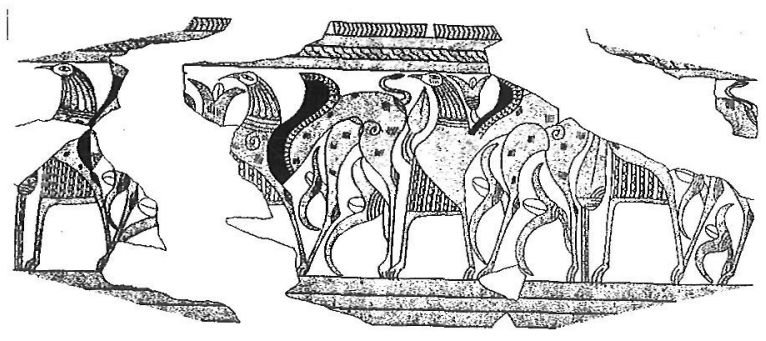

Figura 1: Fila de grifos. Pithos A de Carmona. Según Belén $y$ otros.

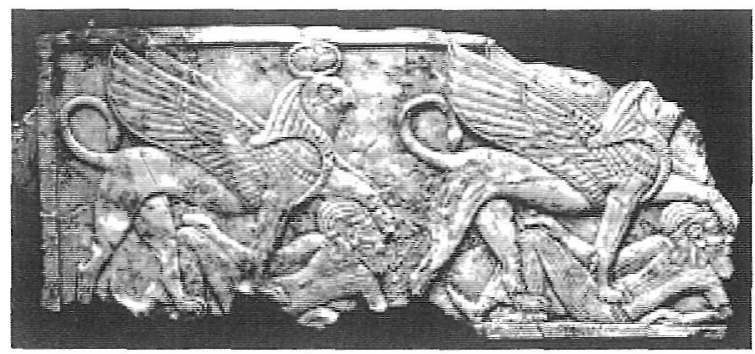

Figura 3: Placa de marfil hallada en el Fuerte de Salmanasar III. Nimrud. Según M.E.L. Mallowan.

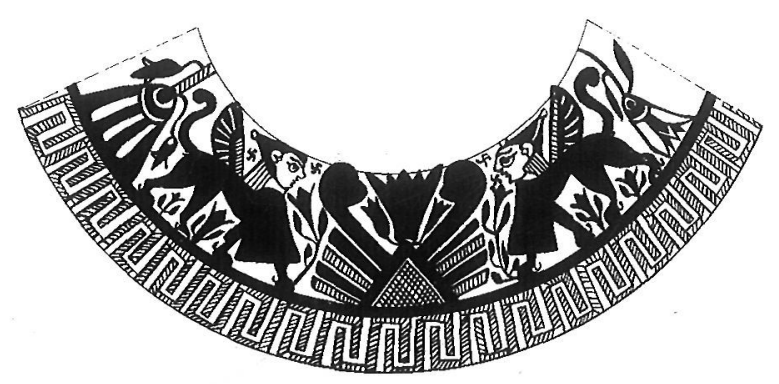

Figura 5: Jarro del Cyprus Museum, Nicosia. Según V. Karageoghis y J. Gagniers.

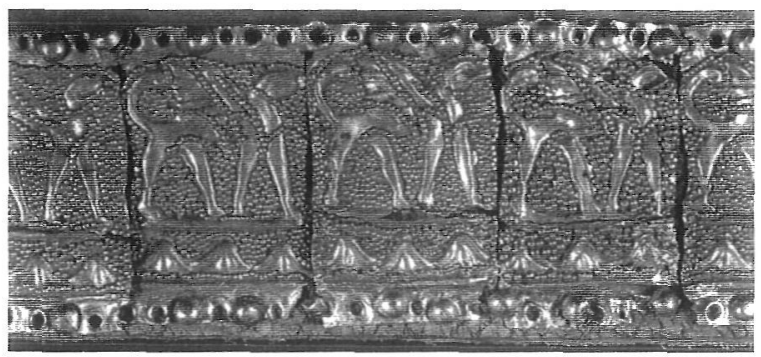

Figura 2: Cinturón de La Aliseda.

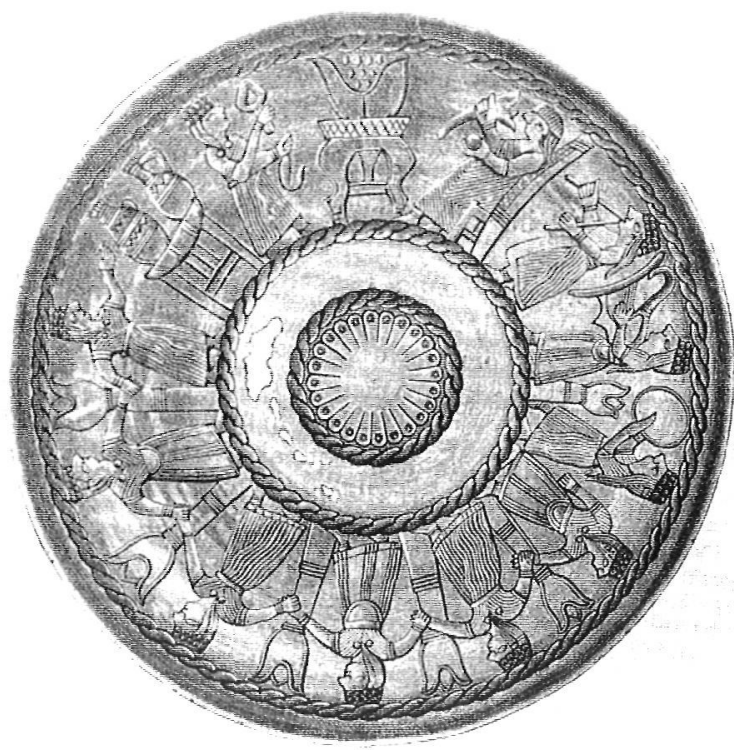

Figura 4: Pátera de bronce de Kurion. Metropolitan Museum of Art, Nueva York. Según G. Markoe.

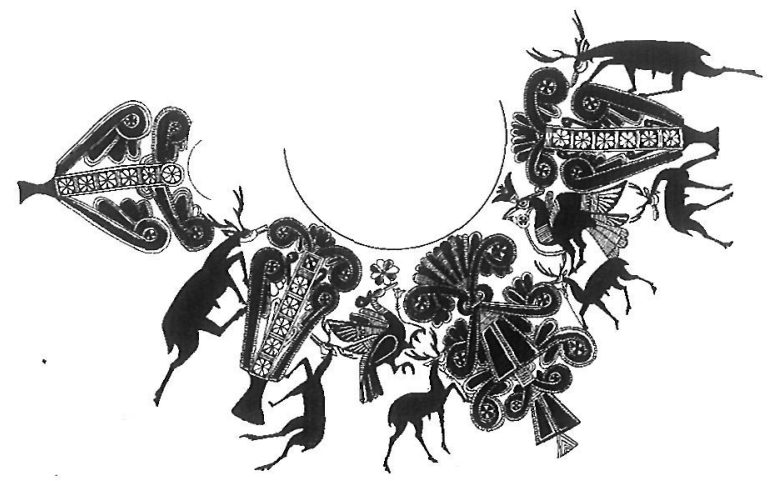

Figura 6: Jarro del Cyprus Museum, Nicosia. Según V. Karageoghis y J. Gagniers. 
LÉN y otros 1998, 145-151, ff. 13-15). El paralelo más próximo a la fila de grifos del pithos $\mathrm{A}$ del santuario de Carmona es la de grifos del cinturón de La Aliseda (Cáceres) ${ }^{5}$ (fig. 2), obra fabricada en torno al 600 a.C., en un taller fenicio, posiblemente asentado en Cádiz o en el castillo de Doña Blanca en las proximidades de Cádiz.

Filas de grifos, alados, sin falderín, en este caso, aplastando a un enemigo vencido y caído en tierra, se representan en una placa de marfil del Fuerte de Salmanasar III, en Nimrud $^{6}$ (fig. 3). Aquí la decoración del cuello de los grifos es muy parecida a la de los grifos de Carmona. La composición de la placa de marfil de Nimrud se repite en otras dos páteras halladas en Chipre, como en una pátera de plata de Idalion, hoy en el Museo del Louvre de París. En esta pieza los grifos alternan con esfinges ${ }^{7}$. La pátera pertenece al período III chiprofenicio de la clasificación de Markoe, fechado por este autor entre la última década del siglo VIII y el primer cuarto del siglo VII a.C.

\section{MOTIVOS ORIENTALIZANTES DEL CINTU- RÓN DE LA ALISEDA}

\section{Palmetas, esfinges y lucha de héroe con león}

En este cinturón, una de las piezas cumbres de la orfebrería hispana de toda la antigüedad, algunos temas decorativos siguen prototipos orientales traídos por los fenicios. Antes de seguir adelante conviene referirse a ellos, ya que son posiblemente los más antiguos en occidente, y por haberse mencionado la fila de grifos como paralelos próximos para la decoración del pithos de Carmona.

La palmeta de cuenco de cepillo del cinturón de La Aliseda ofrece un impresionante paralelo con algunas palmetas de cuenco de cepillo que forman el árbol sagrado de la pátera de plata hallada en Kurion, en la actualidad en el Metropolitan Museum of Art de Nueva York (MARKOE 1985, 177-178), perteneciente al mismo periodo y fecha que la pátera anterior.

Las palmetas de cuenco de cepillo como las de el cinturón de La Aliseda son muy frecuentes en las páteras fenicias. Una de las más significativas corona un árbol sagrado con cabras rampantes en una pátera de bronce encontrada en Fortessa en la actualidad depositada en el Archaeological Museum, Heracleion en Creta (MARKOE 1985, 156, 163-164, 283,
Cr 1), datada en el II periodo de Markoe. Una palmeta de cuenco de cepillo sobre el árbol sagrado se encuentra, igualmente, en la pátera de bronce de Arkades conservada en el mismo museo (MARKOE 1985, 167-168, Cr 12), fechada en el III período de Markoe (710-675 a.C.). En una pátera de plata, hallada en Amathus, guardada en el British Museum de Londres, también datada en el III periodo, el árbol sagrado está formado por dos palmetas de cuenco de cepillo superpuestas (MARKOE 1985, 172-174, Cy 4). Este tipo de árbol sagrado con palmetas de cuenco de cepillo se repite en la pátera de plata encontrada en Kurion a la que nos referimos más adelante (MARKOE 1985, 256, 258-259, Cy 8) (fig. 4). Un árbol sagrado formado por dos palmetas de cuenco de cepillo superpuestas entre esfinges decora un escarabeo de onyx del Museum of Fine Arts de Boston (MARKOE 1985, 371, Comp 17).

La pieza más original, una gigantesca palmeta de cuenco rellena esta vez de flores de loto, con dos grifos en el interior, es una placa de marfil hallada en Nimrud (MALLOWAN 1966). Estas palmetas de cuenco de cepillo, muy estilizadas, forman árboles sagrados en la pintura vascular de Chipre, como sobre el cuello y la panza de una gran ánfora del Cyprus Museum de Nicosia, perteneciente al Bicroma IV-V (KARAGEORGHIS y GAGNIERS 1974, 84-88).

Una variante de estas palmetas de cuenco, aquí con flor de loto en el interior, se encuentra sobre los hombros de una gran ánfora de la misma clase y del mismo museo de Chipre (KARAGEORGHIS y GAGNIERS 1974, 124). Un paralelo muy exacto (fig. 5) para la palmeta de cuenco de cepillo del cinturón de La Aliseda, se documenta en un jarro de periodo Bicroma $V$, hoy conservado en el Cyprus Museum de Nicosia (KARAGEORGHIS y GAGNIERS 1974, 134-135). Palmeta de cuenco con flor de loto sobre un triángulo corona el árbol sagrado entre cabras rampantes de la clase Bicroma IV publicado hace muchos años por Olmefalsch-Richter (KARAGEORGHIS y GAGNIERS 1974, 199).

\footnotetext{
${ }^{5}$ BLANCO 1996, 54-62; BLÁZQUEZ 1988, 219-220; NICOLINI 1990, 503-506, LAM 179-181C.

${ }^{6}$ MALLOWAN 1966, 570-571, f. 521, según el autor son cabezas de halcones. MARKOE 1985, 36-38.

${ }^{7}$ MARKOE $1985,151,170-171,244-245$. Decora el mango de un espejo hallado en una tumba de Palaepaphos, fechada a final del siglo XIII a.C.
} 
Una variante de las palmetas de cuenco de cepillo con puntas dobladas hacia afuera (fig. 6) se pintó, dos veces, en el jarro de la clase Bicroma IV, del Ashmolean Museum de Oxford (KARAGEORGHIS y GAGNIERS 1974, 206207). Las palmetas de cuenco de cepillo están también representadas en la orfebrería etrusca de periodo orientalizante. Baste recordar el pectoral de la Tumba Regolini-Galassi, en torno al 650 a.C., y la lámina de brazalete, piezas a las que nos referiremos más adelante.

Las palmetas de cuenco de cepillo del cinturón de La Aliseda son las más antiguas de Occidente. Estas piezas son importantes para la decoración del piso de una tumba de Galera (Granada) de fecha mucho más posterior, siglo IV a. C. En el cinturón de La Aliseda se colocó un segundo tipo de palmetas de cuenco, esta vez sin cepillo en el interior. Estas filas de palmetas siguen un prototipo con la variante, que una veces se tocan y otras son secantes, como en una ánfora de la clase Bicroma IV guardada en el Cyprus Museum de Nicosia (KARAGEORGHIS y GAGNIERS 1974, 81) (fig. 7).

Esta composición se repite idéntica, sin motivos florales en el interior, en un marfil de Nimrud (MALLOWAN 1966, 102) (fig. 8). No

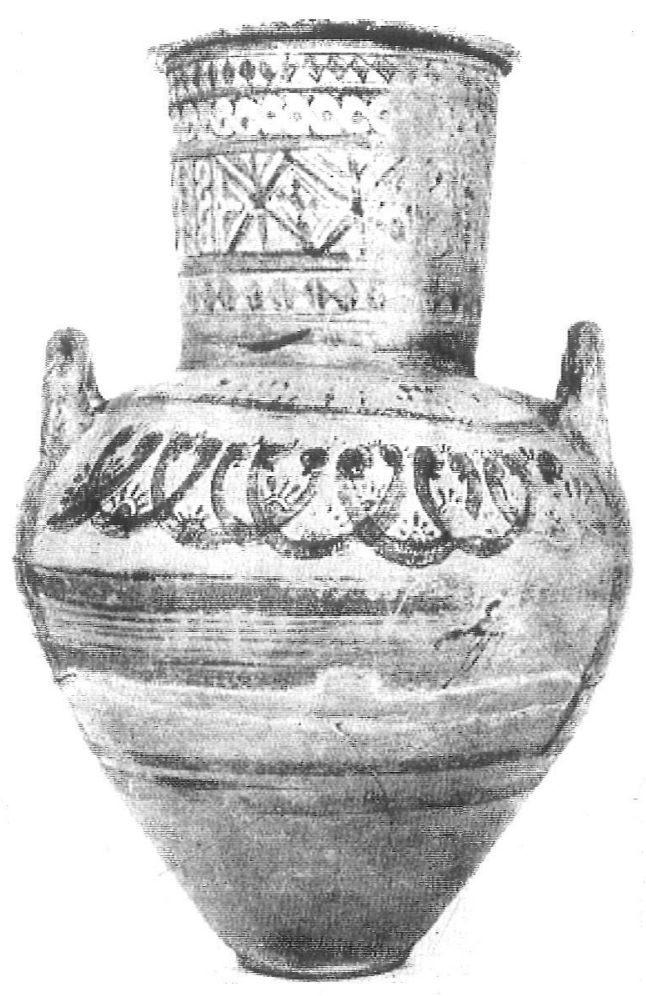

Figura 7: Ánfora del Cyprus Museum, Nicosia. Según V. Karageoghis y J. Gagniers.

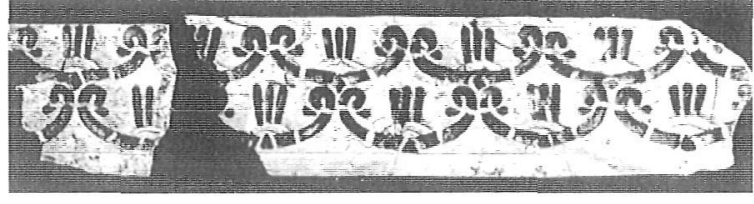

Figura 8: Placa de marfil de Nimrud. Según M.E.I. Mallowan.

es extraño, que temas de la cerámica ibérica o tartésica tengan paralelos en los marfiles de Nimrud, donde trabajaban artesanos fenicios y sirios para los monarcas asirios según Barnett. Artesanos fenicios y sirios son los artífices, según A. Blanco, del grupo más antiguo de marfiles de Carmona. Los bronces del Berrueco (Salamanca), siglo VII a.C., como señaló en su día A. Blanco, tienen un paralelo impresionante en una diosa del Fuerte de Salmanasar III, con un disco sobre el vientre, rodeada de flores de loto y con el peinado de la diosa egipcia Hator, todo como los bronces salmantinos.

En la decoración del cinturón de La Aliseda hay otros dos temas que deben ser tratados con más detenimiento de lo que han sido hasta ahora, pues arrojan mucha luz sobre los influjos orientalizantes en Occidente, bien patentes en las piezas que se estudian en este trabajo.

El primero es la fila de esfinges aladas sin falderín entre las piernas, con la tiara egipcia sobre la cabeza alternado con toros subidos a un plinto. Esta composición se encuentra en uno de los cuencos de bronce de la famosa Gruta de Zeus en el monte Ida en Creta, hoy depositado, al igual que las restantes piezas de este fabuloso conjunto, en el citado Museo Arqueológico, Heracleion (MARKOE $1985,156,164$, Cr 3), perteneciente al II periodo de Markoe (750-700 a. C. $)^{8}$. En el anillo central de la mencionada pátera de Idalion alternan grifo alados con esfinges aladas, sin falderín y sin corona egipcia sobre la cabeza, exactamente igual que en el cinturón de La Aliseda.

Una fila de esfinges aladas sin falderín y sin corona egipcia sobre la cabeza decora el anillo superior de una pátera de bronce de procedencia desconocida, hoy en el Ashmolean Museum de Oxford, datada por Markoe (MARKOE 1985, 156, 210, Ir 3) en el periodo IV (675-625 a.C.) y el anillo superior de una segunda pátera, también de bronce, igualmente de procedencia desconocida, del Museum

\footnotetext{
${ }^{8}$ Sobre las esfinges y grifos MARKOE 1985, 34-36. En los marfiles de Carmona BLANCO 1996, 173-176.
} 


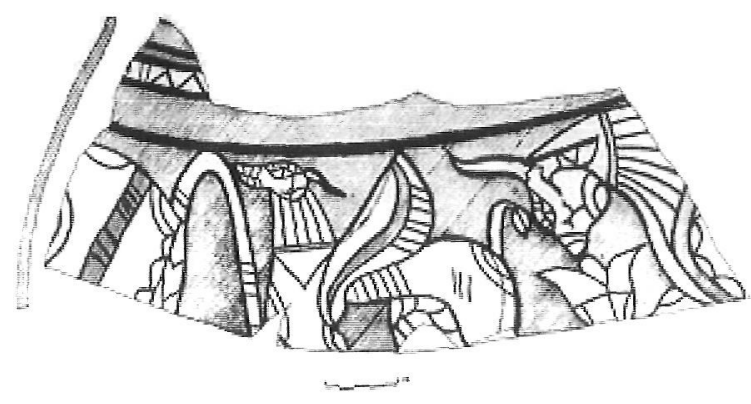

Figura 9: Pithos de Lora del Río con monstruo y toro. Según J. Remesal.

für Kunst and Gewerbe de Hamburgo (MARKOE 1985, 158, 212, Ir 8) de la misma fecha que el cuenco anterior.

Un grupo muy significativo del cinturón de La Aliseda está formado por el héroe, de pie, en lucha con un león rampante, lucha que, cuando se representó en La Aliseda, Ilevaba muchos siglos de moda ${ }^{9}$.

Los artesanos fenicios han colocado este motivo en los grupos de combate con monstruos que decoraban los anillos de sus páteras, como en la citada de Idalion. Aquí el héroe es alado y ataca a la fiera rampante con espada. Héroes clavando la espada en el pecho del león, o sujetándolos por las patas delanteras, se documentan en la mencionada pátera, segunda pieza procedente de Idalion, del Museo del Louvre. En el círculo central de la citada pátera de Kurion, el héroe, tetráptero, y de pie, hunde su lanza en el cuerpo del león rampante. Varón de pie, ayudado por su perro, ataca con una espada a un león rampante en la pieza recogida en la Tumba Bernardini de Praeneste, hoy en el Museo de Villa Giulia de Roma (MARKOE 1985, 191, 192, E3) y en una segunda pátera de Caere de la misma fecha, en torno al 650 a.C., en la actualidad en el museo Gregoriano Etrusco del Vaticano ${ }^{10}$.

El tema se documenta siglos antes en Ras Shamra. El héroe, de pie, clava la lanza en un león rampante auxiliado por un acompañante, que, clava un puñal en la espalda de la fiera (MARKOE 1985, 355, comp. 1 Rasman). Héroes caídos a tierra, protegidos por cascos y escudos, atacan con espada a leones, que les acometen, varias veces, y los acometen de rodilla otras veces, en un escudo de bronce hallado en la Gruta de Zeus en el Monte Ida (MARKOE 1985, 369, Shamra).

Una de las piezas más significativas de este tema es un cuenco de bronce de la antigua colección Layard. El héroe unas veces se le representa entre dos leones rampantes y otras clavando la espada en el cuerpo de la fiera (MARKOE 1985, 357, comp. 3).

El paralelo más exacto para el grupo del cinturón de La Aliseda, sin embargo, se encuentra en el anillo central de la pátera de plata, de origen desconocido, hoy en el Rijks-Museum van Oudheden, de Leiden, fechada entre los años 710-675 a.C., según Markoe (MARKOE 1985, 156, 201, E13).

El cinturón de La Aliseda tenía, muy probablemente, carácter apotropaico, al igual que todos los cinturones anchos con gran placa, que llevaban ciertos varones en los bronces ibéricos, el hombre en lucha con el grifo de Obulco (Porcuna, Jaén), guerrero de Pozo Moro (Albacete), de llici (Elche, Alicante) y el ancho cinturón de Maquiz (Jaén), etc.

El origen sagrado de estos cinturones es de origen iranio, carácter sagrado que pasó a los judíos (Testamento de Jacob) y a los fenicios que introdujeron este carácter en el Occidente. Debido a este carácter apotropaico del cinturón, en el cinturón de La Aliseda los grifos, esfinges, palmetas y héroe en lucha con león tendrían, muy probablemente, carácter apotropaico, como lo tendrían la esfinge alada debajo del sol, también alado, de la sortija de Andújar, siglos VII-VI a. C., o el grifo, del siglo VI a.C., de una tumba de la necrópolis de Huelva.

\section{FILA DE MONSTRUOS Y TOROS DE LORA DEL RIO (SEVILLA)}

La decoración central de un fragmento de pithos de Lora del Río (Sevilla) (REMESAL 1975, 3-7) (fig. 9) de la misma fecha aproximada que el pithos A de Carmona, es un paralelo temático para esta última pintura. Un ser fantástico, no grifo, a juzgar por la cabeza alada, con cola levantada y la extremidad enroscada, camina entre dos animales, uno de los cuales, el posterior, es un toro, que huele una flor de loto.

\footnotetext{
${ }^{9}$ AMIET 1980, f. 762, en torno al 2250, f. 759 hacia el 2400; FRANKFORT 1970, f. 69, estilo protodinástico

${ }^{10}$ MARKOE 1985, 194-196, E6. CRISTOFANI y MARTELLI 1983, 264, F 42. Como ya señaló A. Blanco (BLANCO 1996, $74)$ en el pectoral de la Tumba Regolini Galassi se repiten tres motivos hallados entre los fenicios de Occidente: las palmetas de cuenco de cepillo, el héroe en lucha con el león y la hilera de grifos (CRISTOFANI y MARTELLI 1983, 263, f. 35).
} 


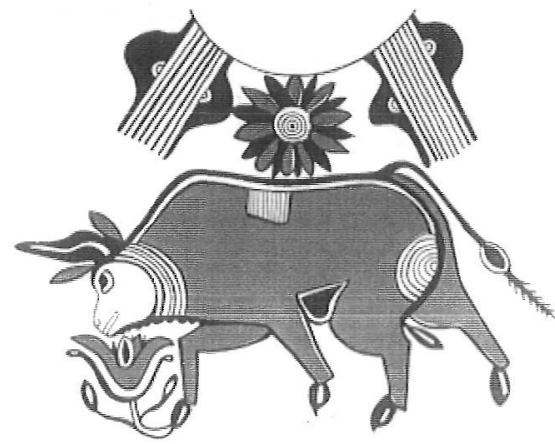

Figura 10: Ánfora del Cyprus Museum, Nicosia. Según V. Karageoghis y J. Gagniers.

Grifos, esfinges y toros son los seres preferidos de los artesanos fenicios del periodo orientalizante en todo tipo de objetos.

Anillos de filas de toros decoran, con mucha frecuencia, las páteras fenicias, como las de bronce procedentes de Francavilla Maritima, Calabria (MARKOE 1985, 161-162, Ca 1, 80$81,143,156)$, datada en el periodo III de Markoe; de la Cueva de Zeus, en el Monte Ida de Creta, hoy en el Museo Arqueológico, Heracleion, de Creta (MARKOE 1985, 156, 164 167, Cr 4), obra de artesanos fenicios, según Dunbabin (DUNBABIN 1957), fechada por Markoe entre los finales del período II de su clasificación (750-700 a.C.) y los inicios del III (710-675 a.C.); de Esparta (?) en la actualidad en el Louvre de París datada en el periodo II de Markoe (MARKOE 1985, 156, 207, 208, G 8); de procedencia desconocida, conservada en el Fitzwilliam Museum de Cambridge (MARKOE $1985,218,342,343, U$ 2) fechada en el periodo II de Markoe; igualmente de procedencia desconocida del Iran Bastan Museum de Teherán (MARKOE 1985, 262, 344, U 2) del mismo periodo. Esta pieza es importante por representar un león entre dos toros, en la pintura de Carmona el toro marcha detrás de un monstruo; de Nimrud de la antigua colección Layard (MARKOE 1985, 356, Comp 2), en el segundo anillo del cuenco el toro sigue a un grifo alado, posiblemente como en Carmona, y por segunda vez a un grifo alado atacado por un felino.

El kotyle de plata encontrado en la Tumba del Duce de Vetulonia (MARKOE 1985, 364, comp. 10), es importante, por estar el toro oliendo aquí una palmeta detrás de un grifo alado, con la cola enroscada, todo como en la pintura del pithos de Carmona. Un último ejemplar de cuenco, esta vez de fayenza, decorado con anillo de toros, cabe recordar procedente de El Kurru ${ }^{11}$.
La composición del toro oliendo una flor de loto es frecuente en la pintura vascular de Chipre. Baste recordar dos toros olfateando una flor de loto a ambos lados, por dos veces, de un motivo vegetal estilizado, de un ánfora de la clase Bicroma IV (KARAGEORGHIS y GAGNIERS 1974, 150-151). El paralelo más próximo a la pintura de Lora del Río se encuentra en un jarro, igualmente de la clase Bicroma IV conservado en el mismo museo ${ }^{12}$ (fig. 10). Encima del animal colocó el pintor un gran rosetón. La escena es aún más completa en la parte superior de la panza de una gran cratera del British Museum de Londres, también perteneciente a la clase Bicroma IV. En esta pieza dos parejas de toros están enfrentados a un motivo vegetal, una gran palmeta de cuenco de cepillo que debe ser una representación de un árbol sagrado. Los toros están rodeados de rosetas de diferentes tamaños. Entre las patas delanteras y traseras se encuentra una flor de loto invertida. Otras cuelgan del pie del motivo floral. Hacia ella parecen dirigirse los bóvidos (KARAGEORGHIS y GAGNIERS 1974, 156157) (fig. 11).

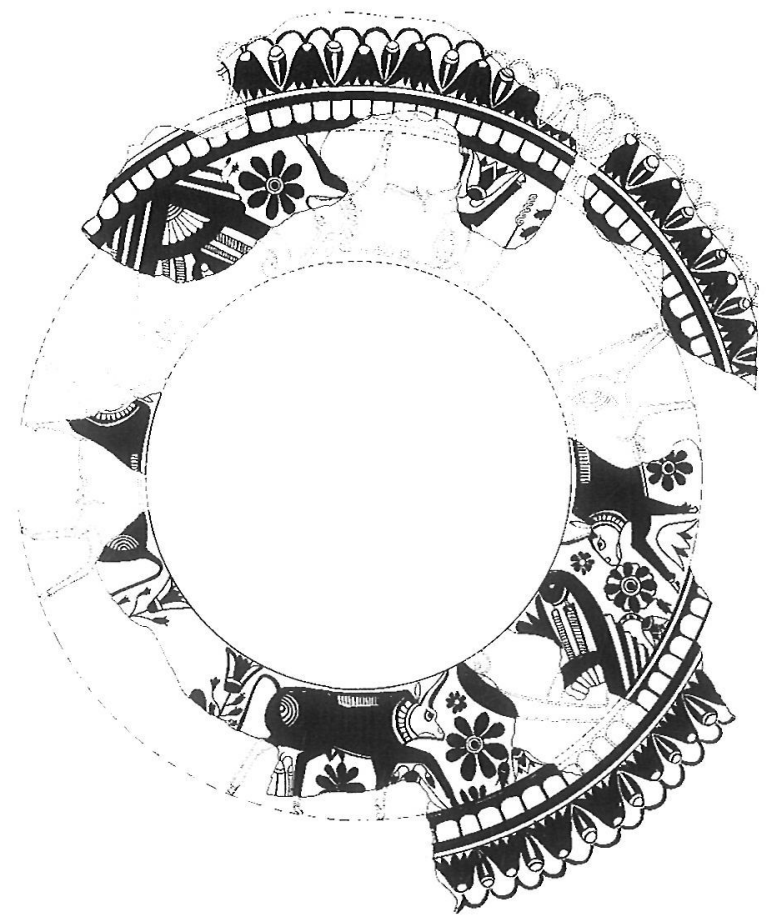

Figura 11: Crátera del British Museum de Londres. Según V. Karageoghis y J. Gagniers.

\footnotetext{
${ }^{11}$ MARKOE 1985, 362, comp. 8. Sobre la representación de toros en las páteras fenicias habla el autor (MARKOE 1985, 38-39).

12 KARAGEORGHIS y GAGNIERS 1974, 166; KARAGEORGHIS 1981, 138-139, f. 105; SPITERIS 1970, 116117 , s. VII a.C.
} 


\section{MOTIVOS VEGETALES EN LOS PITHOI DE CARMONA}

En el segundo pithos (fig. 12) del santuario de Carmona, el tema decorativo consiste en un friso corrido en la parte central, entre dos anchas franjas paralelas. La decoración son sólo flores de loto, capullos y tres rosetones (BELÉN y otros 1998, 151-154, f. 35, fot. 1617). Un tercer pithos (fig. 13) va decorado con una composición parecida a la anterior, con flores y capullos entrelazados, cuatro y tres respectivamente ${ }^{13}$. Idéntico motivo decorativo de capullos y flores de loto, alternando, adorna el anillo superior de la citada pátera hallada en Francavilla Maritima y sólo flores de loto entrelazadas en el citado cuenco del Monte Ida, en Creta. En la pintura vascular chipriota son también frecuentes estos frisos, con flores de loto más gruesas, como en el jarro de la clase Bicroma IV y $V$ del Museo Ermitage de San Petersburgo. Aquí las franjas, dos, son verticales encuadrando la figura central, que es un arquero lanzando su flecha hacia cielo (KARAGEORGHIS y GAGNIERS 1974, 34-35); o en el jarro de la clase Bicroma $V$ del Cyprus Museum de Nicosia (KARAGEORGHIS y GAGNIERS 1974, 54-55), friso de capullos y flores de loto que encuadra una potnia therón (fig. 14), que camina hacia su derecha sosteniendo en alto dos aves, patos a juzgar por la forma del pico. El mismo friso floral vertical flanquea la figura central de varón, de pie, con cabeza cubierta por un bonete, huele una gran flor de loto acercándola con la mano (KARAGEORGHIS y GAGNIERS 1974, 69-70). Las flores de loto son, en la pintura vascular chipriota, mucho más anchas y los capullos mucho más estrechos y pequeños, como en el hombro de una gran ánfora de la clase Bicroma IV hoy en el Cyprus Museum de Nicosia (KARAGEORGHIS y GAGNIERS 1974, 78-80) (fig. 15).

A estos ejemplares es posible añadir alguna otra pieza como el anillo de la panza de la citada crátera del British Museum de Londres.

Todavía cabe recordar como paralelos para las piezas de Carmona otros dos ejemplares de decoración vertical de flores de loto $y$ de capullos sobre un jarro chipriota (KARAGEORGHIS y GAGNIERS 1974, 211) y sobre una gran ánfora de la clase Bicroma $V$ con idéntica decoración sobre la panza (KARAGEORGHIS y GAGNIERS 1974, 248).

Entre los fragmentos de cerámica pintada procedentes de Lora del Río, publicados por
J. Remesal, algunas composiciones completan esta panorama orientalizante. Una pintura representa un árbol sagrado hecho con palmetas de cuenco superpuestas (fig. 16). La composición de otros dos fragmentos es de gran novedad. El motivo decorativo es un aspa de gruesos brazos. Esta decoración se repite varias veces en el exterior de un gran cuenco de la clase Bicroma $V$, de forma cónica y poco profunda del Cyprus Museum de Nicosia (KARAGEORGHIS y GAGNIERS 1974, 93-95) (fig. 17).

Este tema se repite, formando seguramente un árbol sagrado entre esfinges afrontadas en una ánfora de la clase Bicroma $V$, del tantas veces citado museo chipriota de Nicosia (KARAGEORGHIS y GAGNIERS 1974, 127128). En un fragmento de Lora del Río (fig. 18) los capullos de flores de loto son muy gruesos, como los del jarro chipriota con arquero disparando al cielo. Estos dos capullos terminaban los brazos de un árbol sagrado según la acertada reconstrucción de J. Remesal.

Un motivo de Lora del Río de gran novedad es una palmeta de brazos barquiformes, con las puntas dobladas hacia el interior con motivo floral (?), posiblemente un capullo de loto de gran originalidad, en el interior, que recuerda un árbol sagrado con flor de loto en el interior entre dos toros contrapuestos de un jarro de la clase Bicroma IV, hoy en el Cyprus Museum de Nicosia (KARAGEORGHIS y GAGNIERS 1974, 152-153). El paralelo más próximo que conocemos, sin embargo, es una palmeta de cuenco entre aves, con flor de loto de una copa perteneciente al Bicroma IV conservada en el Museo Nacional de Copenhague ${ }^{14}$.

En los santuarios de Cástulo y de El Carambolo, las cerámicas depositadas en ellos son de mejor calidad que las del poblado, al igual que sucede en los santuarios de Chipre.

Los motivos decorativos de estos pithoi de Carmona y de Lora del Río debían tener cierto carácter religioso, o apotropaico, como parece indicar el que decorasen una cerámica expreso para ser depositada en santuarios. La cerámica de Lora no es seguro que proceda de un santuario. A la decoración de los marfiles

\footnotetext{
${ }^{13}$ BELÉN y otros $1998,154-157$, f. 36 , fot. 18-19. En estudios de estos frisos, 157-165.

${ }^{14}$ KARAGEORGHIS y GAGNIERS 1974, 378. También sobre un jarro de la clase Bicroma $V$ del citado museo de Nicosia, 476.
} 

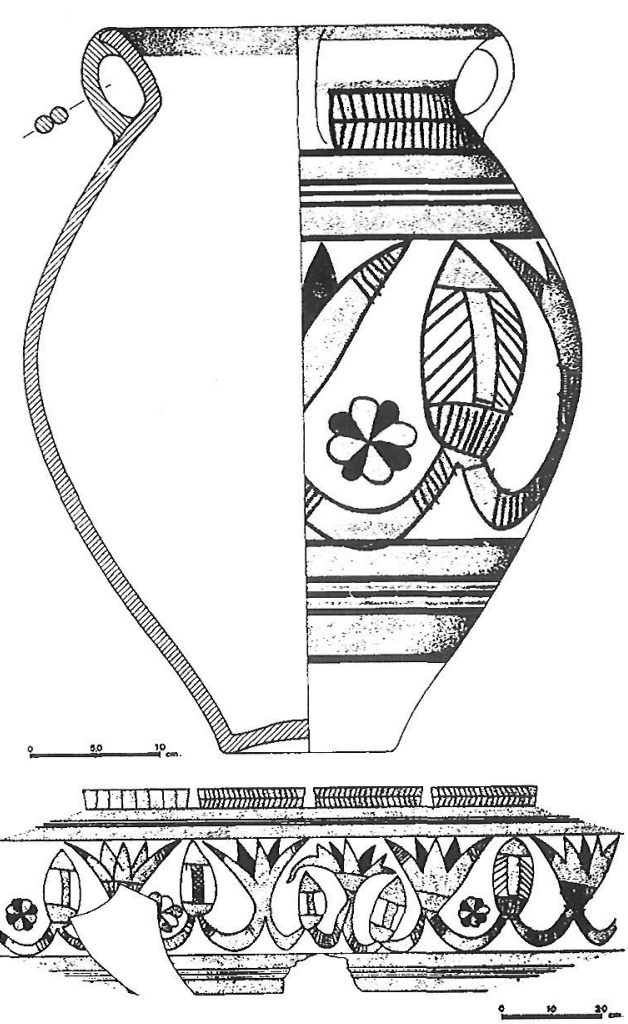

Figura 12: Decoración del Pithos B de Carmona. Según M. Belén.

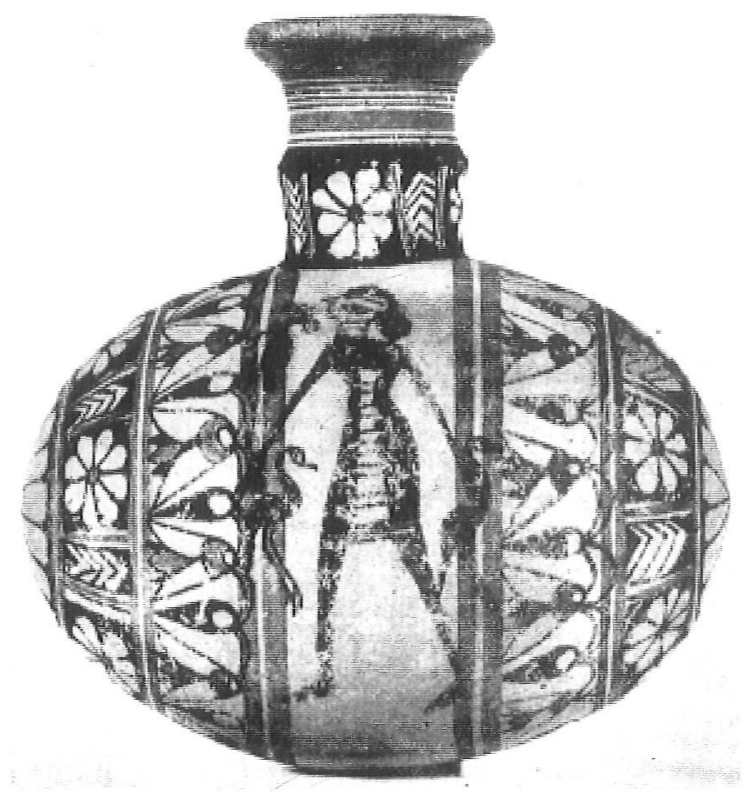

Figura 14: Jarro del Cyprus Museum, Nicosia con potnia theron. Según V. Karageoghis y J. Gagniers.
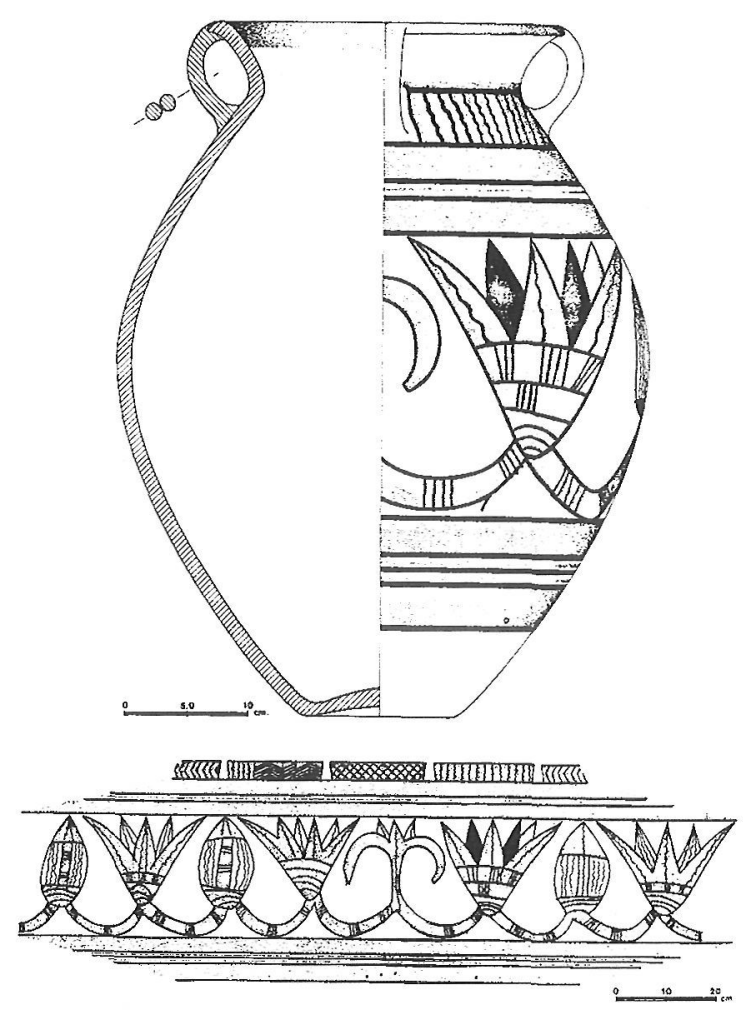

Figura 13: Decoración del Pithos C de Carmona. Según M. Belén.

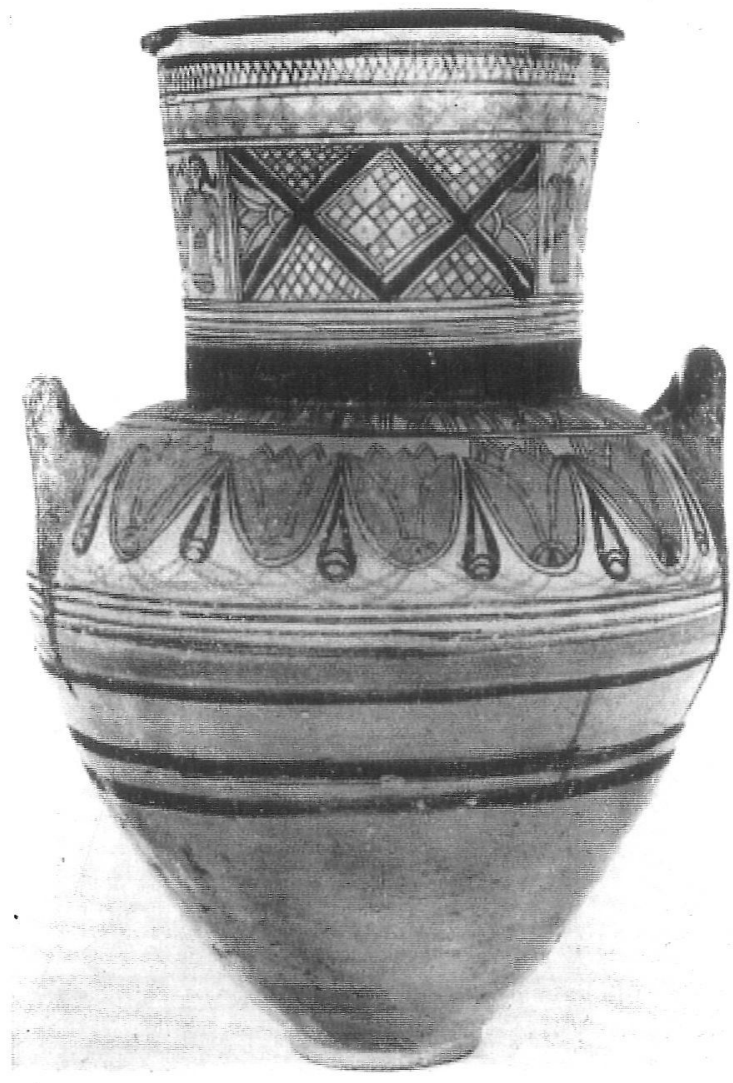

Figura 15: Gran ánfora del Cyprus Museum, Nicosia. Según V. Karageoghis y J. Gagniers. 

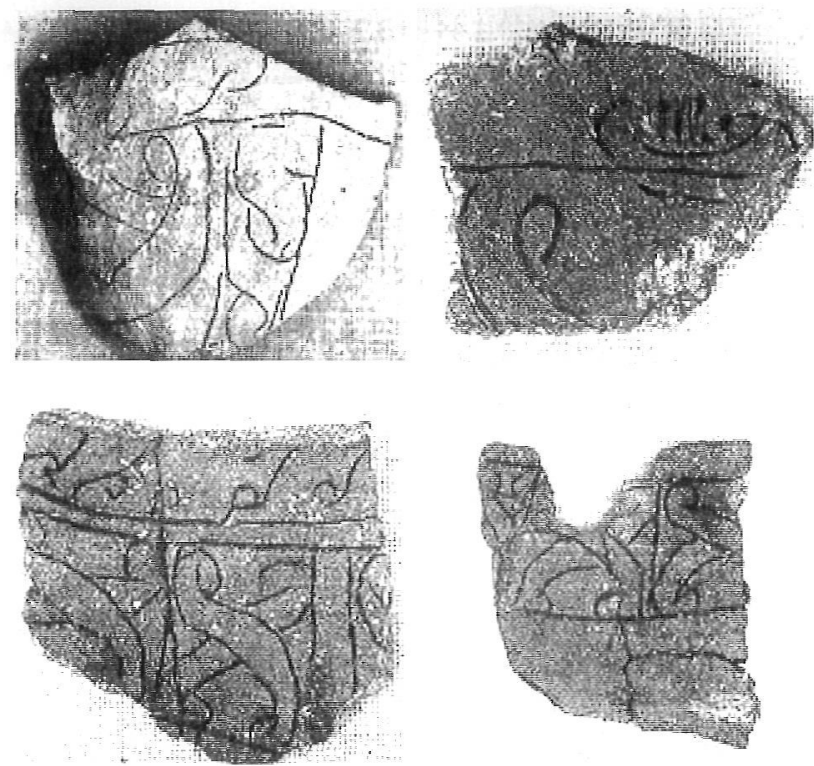

Figura 16: Fragmentos de cerámica pintada, Lora del Río. Según J. Remesal.

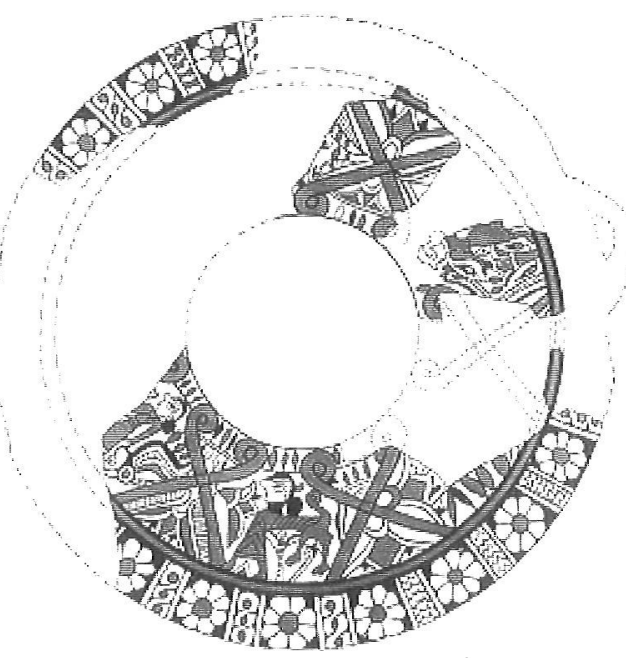

Figura 17: Decoración exterior del gran cuenco del Cyprus Museum, Nicosia. Según V. Karageoghis y J. Gagniers.

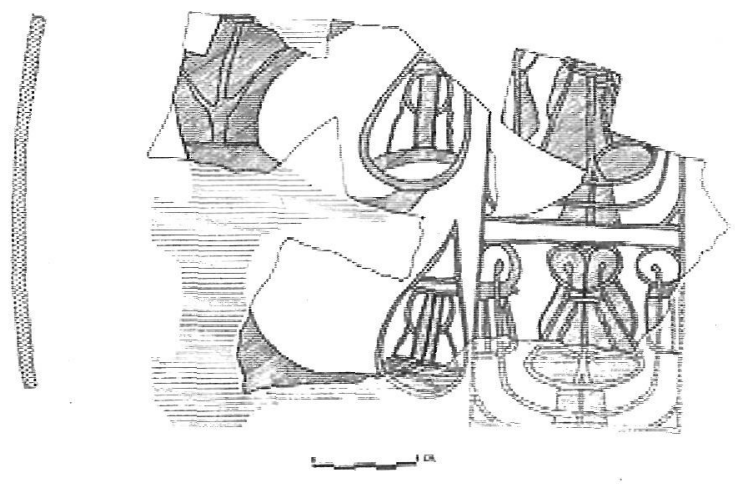

Figura 18: Fragmento de cerámica de Lora del Río. Palmetas de cuenco de cepillo. Según J. Remesal. de Carmona, donde igualmente aparecen grifos, esfinges, lucha de hombres con fieras, etc., A. Blanco no le atribuye ningún carácter religioso, pues estos objetos son de uso doméstico, no de templos.

\section{PINTURAS DEL LEVANTE IBERO}

Algunas composiciones en la pintura vascular ibera responden, muy probablemente, a prototipos traídos a Occidente por los Fenicios.

\section{Leones rampantes ante el árbol sagrado}

Este tema solamente se documenta una vez en Occidente, sobre un vaso de Elche (Alicante $)^{15}$. Leones no rampantes junto a un árbol sagrado decoran la citada pátera de RasShamra.

\section{Friso de aves}

Ya E. Kukaln hace muchos años señaló las conexiones de esta composición, con la del interior de un plato de La Alcudia (Elche) (fig. 19), decorado con friso de aves entre rosetas ${ }^{16}$ (fig. 20), con pinturas del Mediterráneo Oriental. Hoy es posible ofrecer muchos más ejemplos y bibliografía. En la pintura vascular de Chipre se documenta varias veces el mismo tema. Baste recordar el exterior de una copa perteneciente al Bicroma IV del Cyprus Museum de Nicosia (KARAGEORGHIS y GAGNIERS 1974, 192-193) (fig. 21) o una segunda copa de la misma clase guardada en el mismo museo (KARAGEORGHIS y GAGNIERS 1974, 460) (fig. 22) o una tercera copa (KARAGEORGHIS y GAGNIERS 1974, 462) del Micholson Museum de Sydney (fig. 23), o la crátera, igualmente del Bicroma IV del British Museum (fig. 24), reproducida por E. Kukahn (KARAGEORGHIS y GAGNIERS 1974, 465); - la crátera de la colección Hadjipromou de Farmagusta (KARAGEORGHIS y GAGNIERS 1974, 474), etc..

\section{Grifo y árbol sagrado}

Un fragmento pintado, hallado en el Cerro de San Miguel de Liria (Valencia) va decorado con una palmeta, muy estilizada, junto a un cuello y una cabeza de grifo (BLANCO 1996,

\footnotetext{
${ }^{15}$ BLANCO 1996, 239, f. 29; OLMOS 1988-89, 79-102.

${ }^{16}$ PERICOT 1979, 107, f. 137. En un kalathos de Alcalá de Azaila (Teruel), se pintó también una fila de aves (PERICOT 1979, 230, f. 369.
} 


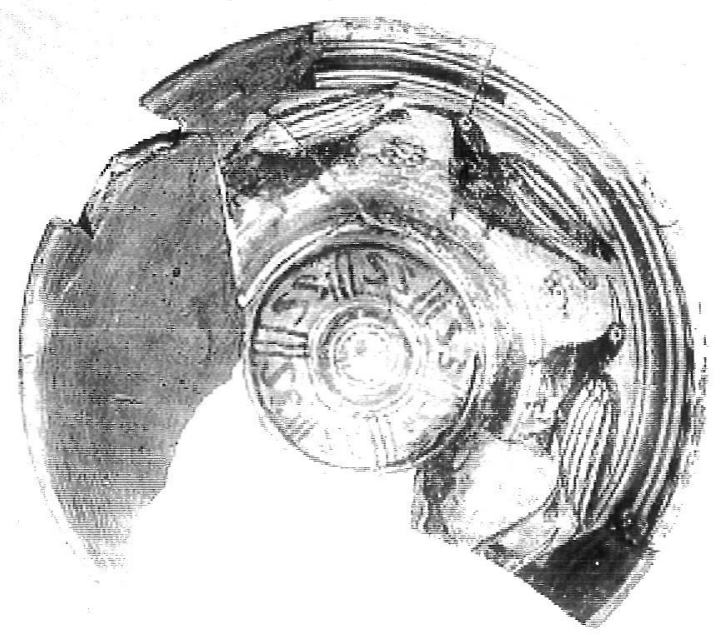

Figura 19: Interior de un plato hallado en La Alcudia. Según L. Pericot.

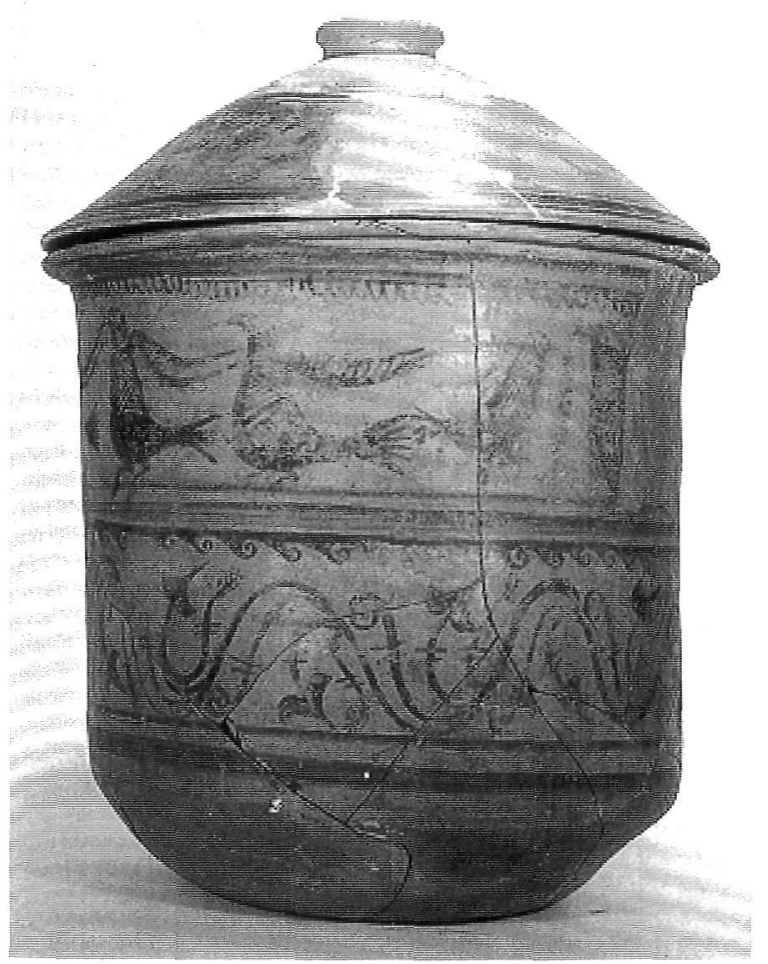

Figura 20: Filas de aves marchando sobre kalathos de Azaila. Según L. Pericot.

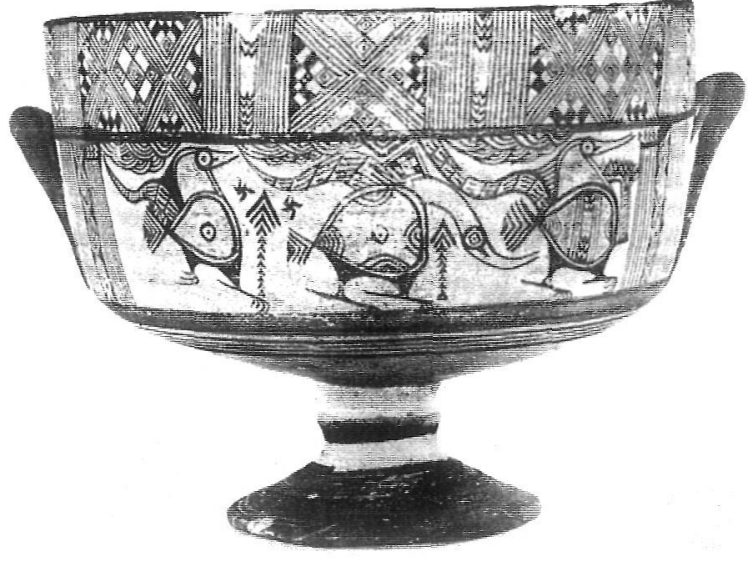

Figura 21: Fila de aves. Copa del Cyprus Museum, Nicosia. Según V. Karageoghis y J. Cagniers.

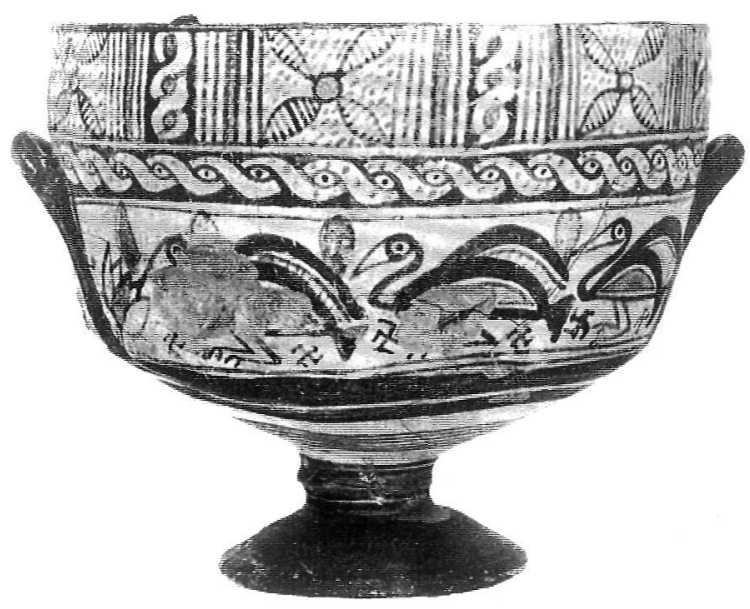

Figura 22: Copa con fila de aves. Cyprus Museum, Nicosia. Según V. Karageoghis y J. Cagniers.

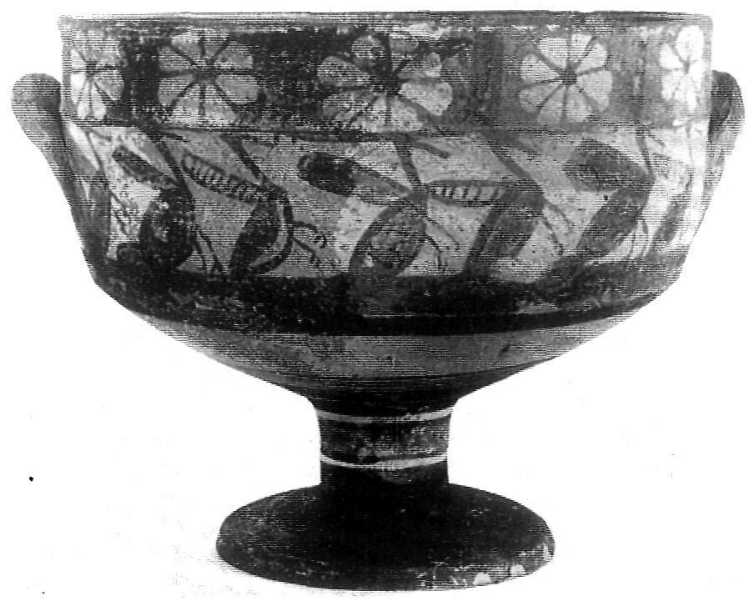

Figura 23: Copa con fila de aves. Nicholson Museum, Sydney. Según V. Karageoghis y J. Cagniers. 


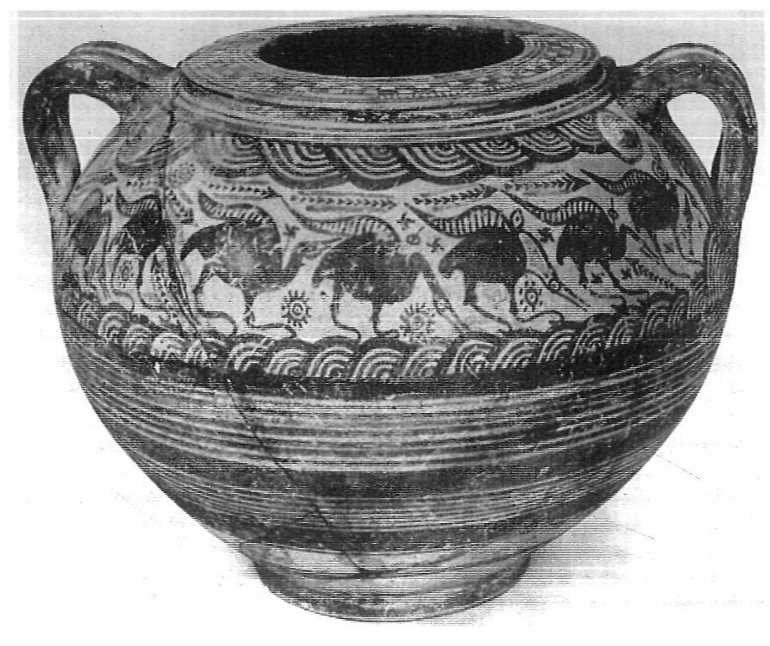

Figura 24: Crátera con fila de aves y rosetas. British Museum. Según V. Karageoghis y J. Cagniers.

72-73, f. 47). Posiblemente no se trata de una paloma, pintada con frecuencia en la cerámica ibera, como lo indican el grosor del cuello, el bucle caído y doblado sobre el cuello, frecuente en las cabezas de grifos y la presencia del árbol sagrado. Este conjunto aparece en páteras fenicias, como en la citada de Kurión, donde el grifo lleva el mismo bucle con el borde enrollado cayendo sobre el cuello. Este bucle caído a un lado de la cabeza del animal es típico de los grifos del período neohitita, de donde los arameos, los sirios o los fenicios lo pudieron traer con la colonización a Occidente. Baste recordar grifos esculpidos en piedra del ortostato de Sakçegözü ${ }^{17}$, de estilo arameo, datado en torno al 730 a.C.; del ostostato de Ankara de estilo arameizante o hitita, fechados hacia el 700 a.C. (AKURGAL 1969, 58, f. 17; AKURGAL 1962, lám111); de la base de columna entre leones hallada en Karquemish, de estilo del paso del arte neohitita antiguo al medio $^{18}$, de la segunda mitad del siglo VIII a.C.; del ortostato de la puerta exterior del Castillo de Sendjirli, de estilo neohitita medio (832-810 a.C. (AKURGAL 1969, 101-102, f. 63) y un segundo hallado en la puerta sur de Sendjirli, de estilo neohitita medio (AKURGAL 1969, 102, f. $65)$, ambos son daimones alados con cabezas de grifo, al igual que el ejemplar de Karquemish, del mismo estilo, fechado en la segunda mitad del siglo VIII (AKURGAL 1969, 102, f. 79). Los grifos de los marfiles de Nimrud suelen llevar estos bucles a los lados de la cabeza, que a veces son hasta tres $^{19}$.

Este tema se repite siglos antes en el VII ó VI a.C., en la hebilla calada de Sancho Reja
(Ávila), con grifo apoyado en una palmeta de cuenco que pica un capullo de loto de un árbol. Esta composición es una variante de la representación de la citada pátera de Kurión, en la que dos grifos alados afrontados a un árbol sagrado, formado por dos palmetas de cuenco superpuestas, la superior de cepillo, huelen una flor de loto. La hebilla de Sancho Reja debe tener un cierto carácter apotropaico por el tema.

\section{Palmetas de cuenco secantes}

El citado dibujo de las palmetas de cuenco entrelazadas decora el cuerpo de tres sombreros de copa hallados en Tosal de les Tenalles (Sidamut, Lérida) (PERICOT 1979, 196, ff. 306307; 108, f. 213) (fig. 25). Una estilización de estos motivos se repiten en la parte inferior del cuerpo de una crátera encontrada en Ampurias (PERICOT 1979, 206, f. 332). El dibujo reaparece en un kalathos encontrado en la Serreta de Alcoy (PERICOT 1979, 142, f. 196).

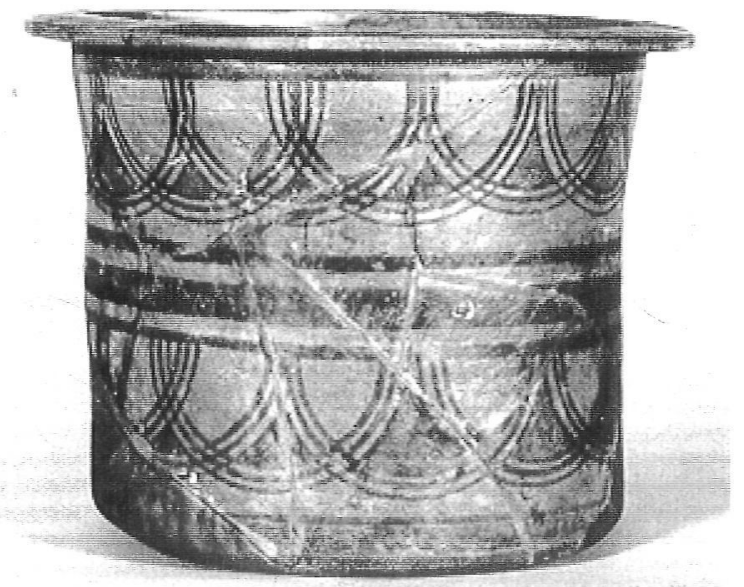

Figura 25: Kalathos con palmetas estilizadas. Tossal de les Tenalles (Sidamunt, Lérida). Según L. Pericot.

${ }_{17}$ AKURGAL 1969, 52, 56, 189, f. 16, lám 15ª AKURGAL 1962, lám 134. Estos bucles ya aparecen en los marfiles micénicos (FRANKFORT 1970, f. 242, 245, 246).

${ }^{18}$ AKURGAL 1969, 103, f. 21a; BITTEL 1976, f. 282. También grifo de la puerta de los leones de Malatya, de finales del siglo VIII a.C., f. 281.

${ }^{19}$ MALLOWAN 1966, 536, ff. 454-455; 454, f. 475; 485, 487, ff. $485-486 ; 564$, f. $508 ; 570$, f. 517 , etc. También en otras culturas orientales: AMIET 1980, f. 660 , prótomo de oro procedente de Ziwiyeh, del siglo VII a.C.; grifo, parte de un trono de una divinidad, ss. VIII-VII a.C., hallado en Rusahimili, Urartu. 


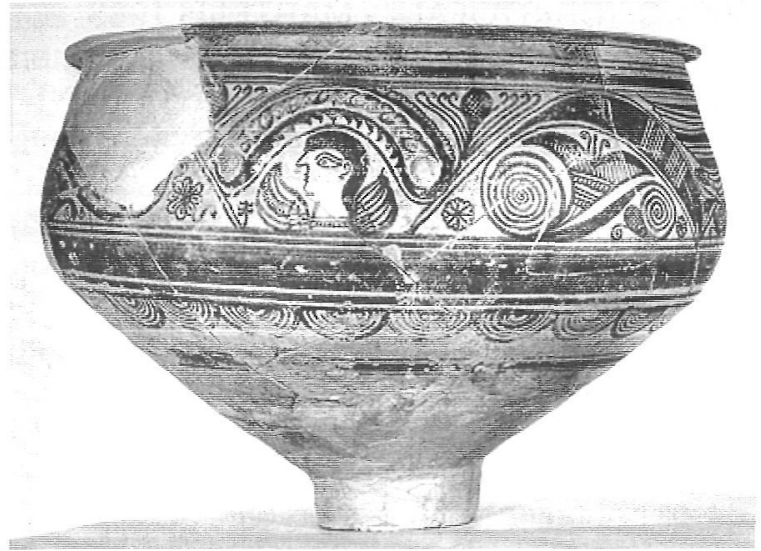

Figura 26: Vaso en forma de embudo con busto de diosa. La Alcudia. Según L. Pericot.

\section{Filas de palmetas}

Filas de palmetas muy estilizadas decoran la parte inferior de una tinaja dentada aparecida en las excavaciones de La Escuera $(\text { Alicante })^{20}$.

\section{Cacería de toro}

Un gran recipiente del Cerro de San Miguel de Liria está decorado con una escena de cacería de toro en la que participan dos varones con mazas enmangadas (PERICOT 1979, 164). El tema es muy de gusto del arte chipriota. Baste recordar un ritón de Kition fechado en la segunda mitad del siglo XIII a.C., (KARAGEORGHIS y GAGNIERS 1974, 43); el jarro de la clase Bicroma IV del Pitt Museum de Oxford, decorado con hombre con larga vara ante toro (KARAGEORGHIS y GAGNIERS 1974, 44-45), al que intenta agarrar por los cuernos, tema que se repite también en un sarcófago chipriota y en una ánfora de la misma clase, hoy en el Cyprus Museum de Nicosia. El varón lleva una larga vara y tira del animal con una soga (KARAGEORGHIS y GAGNIERS 1974, 46-47). La escena del Cerro de San Miguel de Liria podía perfectamente responder a una cacería del mundo ibero y no acusar influjos exteriores

\section{Máscaras humanas}

En la cerámica ibérica levantina se representan con frecuencia máscaras humanas femeninas que se identifican con diosas.

En un gran vaso de ánfora de embudo, hallado en La Alcudia, debajo de las asas se pintó una cabeza de mujer alada, entre dos rosetas. Las alas indican que se trata de una diosa acompañada de sus atributos, la roseta
(PERICOT 1979, 91-93, f. 115) (fig. 26). Un fragmento en un relieve de la misma procedencia va decorado con una cabeza femenina de grandes ojos abiertos y pómulos coloreados $^{21}$. Se trata, muy probablemente, de la máscara de una diosa, a juzgar por el colorido de los pómulos, por las razones que se exponen más adelante.

Sobre el cuerpo de un kalathos se pintó un busto de mujer, con la cabeza de perfil, con alas y con palmas en las manos (PERICOT 1979,118, f. 154). Las alas indican que se representó una diosa.

Debajo de las asas del llamado Vaso de la Pepona colocó el artesano una cara ovalada con dos pómulos bien pintados con grandes círculos, también acompañada de sus atributos, las rosetas (PERICOT 1979, 102-103, f. 127) (fig. 27). La parte interior central de un kernos

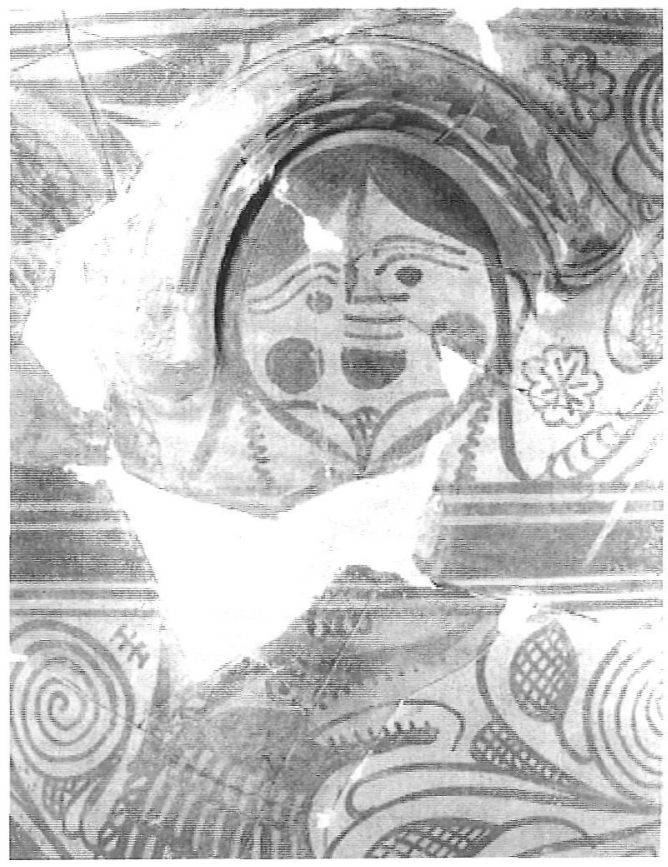

Figura 27: Vaso llamado de la Pepona. La Alcudia. Según L. Pericot.

\footnotetext{
${ }^{20}$ PERICOT 1979, 63, f. 83. Esta decoración de palmetas entrelazadas se repite en una tinaja de Hoya de Santa Ana (Albacete) (PERICOT 1979, 25, f. 27). Este autor interpreta el motivo como semicírculos secantes. No se puede descartar que se trate de palmetas secantes, pues en la cerámica chipriota y en los marfiles de Nimrud son con seguridad palmetas de cuenco secantes y también en el arte etrusco del periodo orientalizante, como en el borde y en el centro de la tumba Regolini-Galassi (CRISTOFANI y MARTELLI 1983, 263, f. 32; RAMOS 1992-94, 127-130).

${ }^{21}$ PERICOT 1979, 116, f. 153. Las máscaras humanas más antiguas de Occidente se hallan en Huelva, s. VI a.C., y en un anillo de La Aliseda, hacia el 600 a.C., joya importada (NICOLINI 1990, 364-366, f. 85).
} 
va decorada con una cabeza parecida, rodeada de sus atributos, en este caso, diferentes animales $^{22}$. Estas máscaras rodeadas de rosetas y de otros atributos divinos, como animales, son imágenes de la diosa Tanit, que era la diosa venerada en La Alcudia como se deduce de un semis con representación de un templo, en cuyo arquitrabe se lee IVNONI, diosa romana equivalente a Tanit (GUADÁN 1980, 261, n. 1017). R. Ramos piensa también que la diosa alada de Elche sea Tanit, que nosotros creemos que es la misma de los pebeteros (POVEDA 1997, 25-61) con busto de dama alada (MARÍN CEVALLOS 1987, 43-79), con atributos astrales sobre el pecho. Es la misma dio$\mathrm{sa}^{23}$ de la tapa del sarcófago de Cartago, según acertada tesis de M.E. Aubet (AUBET, 1976: 61-82). La máscara humana más antigua, siglo VI a.C., hallada en Occidente, se encuentra sobre un braserillo de Huelva, fechado en el siglo VI a.C., aquí la máscara es una imagen de Astarté24. Las ánforas del llamado estilo de Amathunte, 4-7, llevan pintadas una o varias cabezas con el peinado de la diosa egipcia Hathor (KARAGEORGHIS y GAGNIERS 1974, (508-511).

Los pómulos pintados en la cerámica ibera lo llevan los rostros de diosas o las bailarinas sagradas. Ya E. Kukahn relacionó las máscaras humanas iberas con las de la diosa Hathor de la cerámica chipriota y máscaras humanas se pintan en los huevos de avestruz de Cartago. Estas máscaras están prácticamente ausentes en la cerámica griega.

En dos fragmentos de una ánfora de la clase bricrome V, del estilo de Amathunte 8, la decoración consiste en dos caras de perfil puntiagudo con pómulos pintados ${ }^{25}$ como las caras de la Tanit ibera. La cara de forma picuda es la misma que la de Tanit o Astarté de la tinaja de La Alcudia, con diosa alada entre caballos rampantes ${ }^{26}$.

E. Kukahn fecha la cabeza de Olite en el siglo II a.C., y la relaciona con máscaras humanas de Centuripe, en Italia y con máscaras indígenas del sur de Italia. Todas estas caras de diosa y sus atributos sobre la cerámica indican lo profundamente religiosa que era la pintura ibera. La cultura ibera estaba impregnada de lo religioso, como todas las de la antigüedad hasta el mundo moderno. Máscaras también aparecen en la joyería etrusca. Baste recordar las cuatro filas de máscaras que decoran el ya citado brazalete de Vetulonia, las placas de oro con cabeza halladas en la tumba Aureli II de Bolonia, del último cuarto del siglo
VII a.C. (CRISTOFANI y MARTELLI 1983, 274, f. 75); o el collar de Palestrina de la primera mitad del siglo VII a.C. (CRISTOFANI y MARTELLI 1983, 277-278, f. 87); o el collar encontrado en Vulci, datado en torno al 350 a.C. (CRISTOFANI y MARTELLI 1983, 306, f. 220), esta última cabeza debe ser de carácter decorativo, etc.

En la orfebrería griega, igualmente, las máscaras humanas están presentes: tres aniIlos aureos de Megara de finales del siglo VIII a.C. (ROCCHETI, 1992, 246, f. 60), del periodo orientalizante, interpretadas las cabezas como Astarté (ROCCHETI, 1992, 248, f. 75), lo que es muy probable, ya que en un segundo collar (ROCCHETI, 1992, 249, f. 76) y en un tercero (ROCCHETI, 1992, 249, f. 77) de la misma procedencia aparece una potnia theron alada, acompañada de leones y dos colgantes de dos rosetas, atributos de la diosa en la cerámica ibérica; colgante de la misma procedencia, también del periodo orientalizante con potnia theron desnuda, con cabeza de león sobre la testa de la diosa y dos cabezas humanas sobre la del león, rodeada de rosetas, símbolo de la diosa, atributos importantes para la Tanit de la cerámica ibérica (ROCCHETI, 1992, 249 , f. 80), etc.

De particular importancia es una crátera de La Alcudia publicada por R. Ramos. Una gran cara con los pómulos bien pintados y con alas sobre los hombros, lo que indica que se trata de una diosa, decora un lado. En el reverso se pintaron dos cabezas varoniles barbadas, contrapuestas, con dos serpientes entre ellas. De las varias posibles interpretaciones propues-

\footnotetext{
${ }^{22}$ PERICOT 1979, 108, f. 138. Debajo de un asa de Tossal de Manises (Alicante) se encuentra un busto de dama, con cabeza de perfil y los brazos levantados, acompañados de la roseta como atributo (PERICOT 1979, 65, f. 85).

${ }^{23}$ Pebeteros en forma de cabeza femenina relacionados claramente con Tanit han estudiado: ALMAGO GORBEA 1980, 307-308; NÚNẼ GALIANO 1985, 3-6; PENA 1984, 349358; PENA 1987, 1109-1118; PENA 1990, 55-56.

${ }^{24}$ HUSS 1993; BLANCO, CUNCHILLOS y MOLINA (eds) 1994; MATA 1995, 225-244; OLIVER 1995, 282-296; GONZÁLEZ PRATS 1991\% 109-118; LÓPEZ CASTRO 1995.

${ }^{25}$ KARAGEORGHIS y GAGNIERS 1974,511 . Una copia de bronce de Nimrud va decorada en el centro con cuatro cabezas formando un círculo (FRANFORT 1970, f. 302)

${ }^{26}$ BLÁZQUEZ 1997, 79-95. Sobre Tanit o Astarté entre los iberos y turdetanos: BLÁZQUEZ 1975a, 30-39; BLÁZQUEZ 1982, passim; BLÁZQUEZ 1999a, 175-199. Sobre las esculturas ibéricas que son imágenes de diosas: BLANCO $1988,32-48$, a la que hay que añadir la Tanit alada delante de una esfinge (RAMOS 1988, 97-97). Sobre el carácter religioso del carnicero. BLANCO 1993, 86-87; ALMAGRO GORBEA 1996.
} 


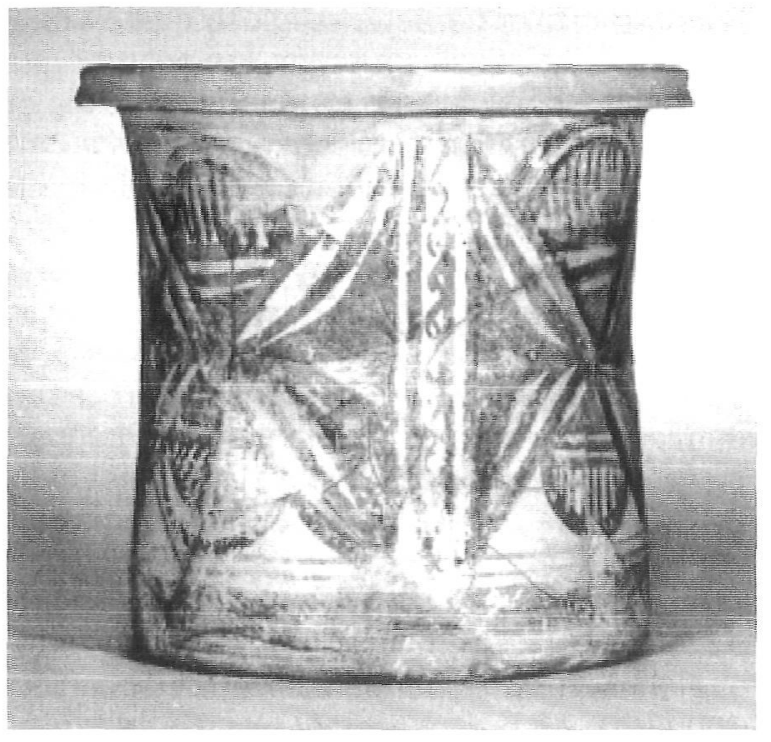

Figura 28: Kalathos decorado con rosetones de Tossal de la Cala (Alicante). Según L. Pericot.

tas por R. Ramos, nos inclinamos por pensar que se trate de dos personajes heroizados, el busto de Tanit tendría carácter funerario. La heoización está bien documentada en Occidente: jinete de los Villares y guerrero de Pozo Moro, ambos en Albacete, placa de Cástulo con jinete. Heroizados debieron estar los personajes enterrados en los heroon de Huelma, comienzos del siglo IV a.C., Obulco (Jaén), segunda mitad del siglo V a.C., y Osuna (Sevilla) siglo III a.C.

En cambio no, creemos que los reyes iberos fueran divinizados, como lo fueron los de Ugarit, donde una lista menciona 52 reyes divinizados. Sí recibió honores divinos de los indígenas Cecilio Metelo, durante la Guerra Sertoriana.

Ramos, con motivo de estudiar las máscaras funerarias ibéricas, recuerda los tres rostros pintados, dentro de decoración vegetal, sobre las dos puertas laterales del vestíbulo y sobre la central de la Tumba François de Vulci. La unión de máscaras y los temas vegetales tienen paralelos en modelos suritálicos (templo de Minerva en Canusium) y en Etruria (tumba Campanari de Vulci). También en la cerámica de Volterra, de Chiusi y de Apulia (Canosa, Centuripe, Volsinii y Campania). Nos inclinamos más bien por prototipos fenicios para la pintura ibérica levantina.

\section{Rosetones entre metopas}

En la pintura vascular ibera se documentan unos rosetones de tamaño grande, hechos con cuatro pétalos, como en un Kalathos de Tossal de la Cala (Alicante) ${ }^{27}$. Aquí aparece próximo a un ala, que es otro de los símbolos de la diosa, en la pintura vascular ibera, ya sola, ya en compañía de rosetas o de vegetales. Precisamente, amontonar los símbolos, es una de las características de la pintura ibera. Sobre un segundo ejemplar de la misma procedencia (PERICOT 1979, 56, f. 74) estos rosetones forman un friso corrido (fig. 28); sobre un Kalathos de La Alcudia (PERICOT 1979, 82, f. 103) y en una tinaja hallada en el mismo yacimiento (PERICOT 1979, 124, f. 165). Este motivo decorativo de rosetones de cuatro pétalos decora la parte delantera de la túnica, que viste la diosa con las alas desplegadas en una tinaja de La Alcudia, pintura a la que nos referiremos más adelante.

Esta es una composición floral bien documentada en la pintura vascular chipriota, como sucede en una jarra de la clase Bicroma IV, entre dos flores de loto (KARAGEORGHIS y GAGNIERS 1974, 310-311). El motivo no es raro en Chipre, al igual que en la pintura vascular ibera, que pudiera ser indígena, aunque más probablemente sea producto de influjos exteriores al levante ibérico.

Los paralelos para el motivo floral ibérico se encuentran sobre el cuello exterior de una copa, también de la clase Bicroma IV, del Cyprus Museum de Nicosia, donde se repite dentro de metopas, como en las pinturas ibéricas (KARAGEORGHIS y GAGNIERS 1974, 460-461). Un segundo paralelo se encuentra en la crátera del Bicroma IV del Cyprus Museum de Nicosia (KARAGEORGHIS y GAGNIERS 1974, 345).

\section{Rosetones}

Un gran rosetón de seis pétalos se representó entre las cabezas de dos bailarinas, cogidas por la mano, sobre un kalathos de San

\footnotetext{
${ }^{27}$ PERICOT 1979, 55, f. 71. Los motivos en aspa son muy frecuentes, baste recordar un soporte de lámpara de la clase Bicroma III (KARAGEORGHIS y GAGNIERS 1974, 271) una crátera de la colección Kolokassides de Nicosia, entre metopas (KARAGEORGHIS y GAGNIERS 1974, 240); crátera de la clase Bicroma IV del Cyprus Museum de Chipre (KARAGEORGHIS y GAGNIERS 1974, 346-347), así como una copa de la misma clase y museo (KARAGEORGHIS y GAGNIERS 1974, 460-461). En todas estas piezas el aspa debe ser méramente decorativa. Este motivo decorativo se encuentra en el colgante del Tesoro del Carambolo (550 a.C.) (NICOLINI 1990, 455-456, lams. 140c-141c) y en joyas de Extremadura (NICOLINI 1990, 525-526, láms 276a-278b).
} 


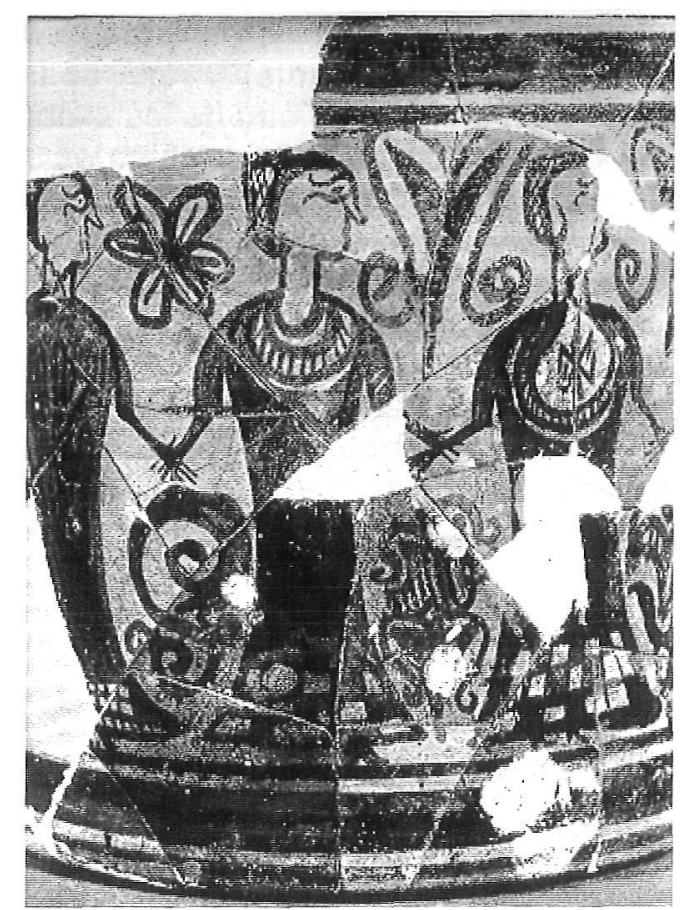

Figura 29: Kalathos del Cerro de San Miguel de Liria con escena de baile y rosetón. Según L. Pericot.

Miguel de Liria ${ }^{28}$ (fig. 29). En la orfebrería etrusca también se documentan grandes rosetones de cuatro pétalos, como en dos pendientes hallados en tumbas de Vulci, datados en el tercer cuarto del siglo VI a.C. (CRISTOFANI y MARTELLI 1983, 288, f. 123); en un pendiente de Chiusi (CRISTOFANI y MARTELLI 1983, 292 , f. 143), de la segunda mitad del siglo VI a.C., y en otro de Cerveteri de la misma fecha (CRISTOFANI y MARTELLI 1983, 292, f. 144). Otras veces los rosetones encuadrados son de muchos pétalos, como en las placas de Veio, de la tumba de Pantanaccio, datada en el tercer cuarto del siglo VI a.C. (CRISTOFANI y MARTELLI 1983, 288, f. 122), de un tipo bien conocido en ambientes greco-orientales, como en Éfeso y Rodas; o en los colgantes hallados en Bientina, del segundo cuarto del siglo $\mathrm{V}$ a.C. (CRISTOFANI y MARTELLI 1983, 290-291, f. 136), etc.

Una gran roseta colocó el pintor ibero detrás del citado busto de una diosa, con los brazos abiertos debajo del fragmento del asa de Tossal de Manises. Todos estos rosetones entre metopas probablemente tenían una mera función decorativa.

\section{Carácter religioso de la danza ibera}

La danza, al igual que las procesiones representadas en la cerámica ibérica, debían tener en mismo carácter religioso que en principio tuvo la danza en todas las culturas durante muchos siglos, no tratándose de simples motivos decorativos ${ }^{29}$.

La danza de damas cogidas de la mano es desconocida en la pintura funeraria etrusca (STEINGRÄBER 1984, passim) y en la de Ruvo (MAURI 1953, 15, 17-18) es de tipo diferente. Sí se documenta en las danzas fúnebres de la cerámica del Dípilon en Atenas, pero estas danzas no sirven de modelo para las ibéricas.

En cambio, es muy frecuente en el mundo semita de Chipre, como en el cuenco fenicio hallado en la Cueva de Zeus, en el Monte Ida, hoy en el Archaeological Museum, Heracleion de Creta (MARKOE 1985, 164, Cr 7), fechado en el periodo II de Markoe (750700 a.C.); en una pátera de bronce de Idalion (fig. 30), en la actualidad en el Metropolitan Museum of Art de Nueva York, datada en el periodo I de Markoe (850-750 a.C.). Aquí, las bailarinas, precedidas de músicas, se dirigen hacia una diosa entronizada delante de mesas de ofrendas. En esta pieza, con toda seguri-

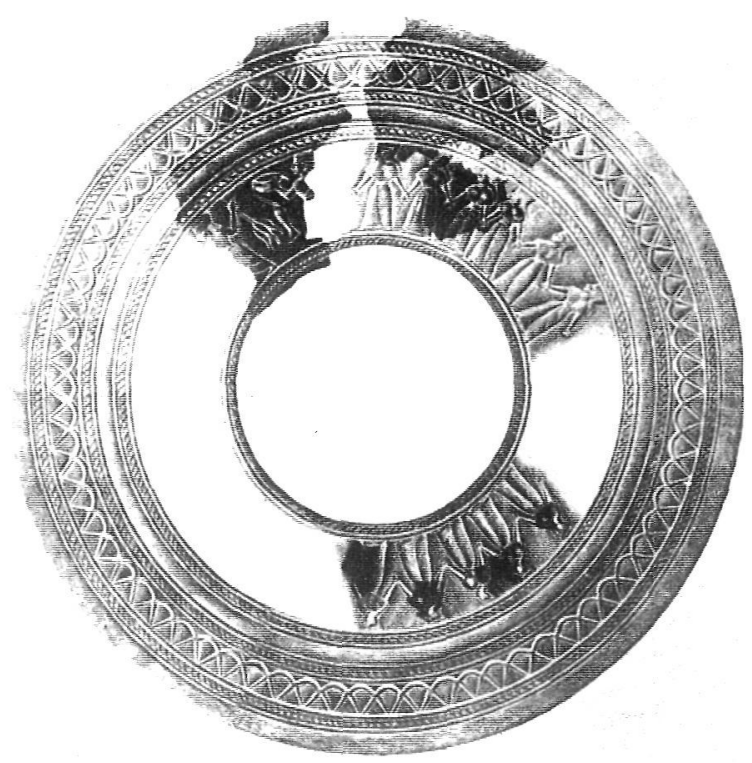

Figura 30: Pátera de Idalion con representación del ritual de una danza sagrada ante diosa. Según Gl. Markoe.

\footnotetext{
28 PERICOT 1979, 173-174, 261-262. Rosetones de muchos pétalos decoran frecuentemente colgantes y pendientes de Cádiz, del siglo IV a.C. (NICOLINI 1990, 460-465, láms 144c148) y el pendiente de Santiago de La Espada del s. VI a.C. (NICOLINI 1990, 335-336, lám 74c-d).

${ }^{29}$ BLÁZQUEZ 1975a, 77; BLÁZQUEZ 1982, passim. Sobre las procesiones y danzas hacia una figura entronizada en las pateras fenicias: MARKOE 1985, 56-57.
} 
dad, se ha representado una danza religiosa ${ }^{30}$, al igual que en la mencionada pieza de Essanta.

Es un tipo de danza totalmente diferente del representado, por dos veces, en el cuenco de plata, de procedencia desconocida, del Cleveland Museum of $\mathrm{Art}^{31}$, fechado entre los años 710-675 a.C. El hecho de que la danza pintada en San Miguel de Liria sea de carácter religioso indica, muy probablemente, que el rosetón no es un simple motivo decorativo, sino el símbolo que acompañaba a la diosa.

\section{Rosetones en la pintura vascular de Chipre}

En la pintura vascular chipriota aparecen, igualmente, grandes rosetones. Cinco detrás de un arpista en un kalathos perteneciente a la pintura protoblanca del Cyprus Museum de Nicosia ${ }^{32}$; también aparecen en el jarro de la Colección Kolokassides de Nicosia (KARAGEORGHIS y GAGNIERS 1974, 310-311). En esta última pieza el carácter religioso del símbolo astral es más evidente al encontrarse entre dos flores de loto. La flor de loto es una planta muy vinculada a Astarté, ya que esta diosa, frecuentemente, sostiene en su mano una flor de loto, como en la citada ánfora de Ormidha y en las páteras de Idalion, de Olimpia y del Iran Bastan Museum.

Un gran rosetón sobre un toro se encuentra en el citado jarro Kolokassides, en el que, además, el toro está oliendo una flor de loto. El carácter sagrado o de símbolo del rosetón queda bien patente en la escena del jarro de la clase Bicroma IV del Museo del Louvre, donde un enorme rosetón, de ocho grandes pétalos, corona lo que probablemente es un árbol sagrado, compuesto por dos palmetas de cuenco superpuestas, terminadas en capullos de loto, con dos flores de la misma planta entre ellos (KARAGEORGHIS y GAGNIERS 1974, 362363) (fig. 31).

Dos rosetones de gran tamaño se encuentran delante del hocico de los dos toros afrontados a un árbol sagrado, en la citada crátera del British Museum.

E. Kukahn a este respecto menciona una terracota ofrecida a la diosa Aphaia de Egina, que lleva un gran rosetón.

\section{Rosetones en la orfebrería etrusca}

En la orfebrería etrusca se documentan bien los rosetones. Ya se ha aludido a rosetones grandes de más de cuatro pétalos. Una pieza muy importante es la lámina de Narce, fe-

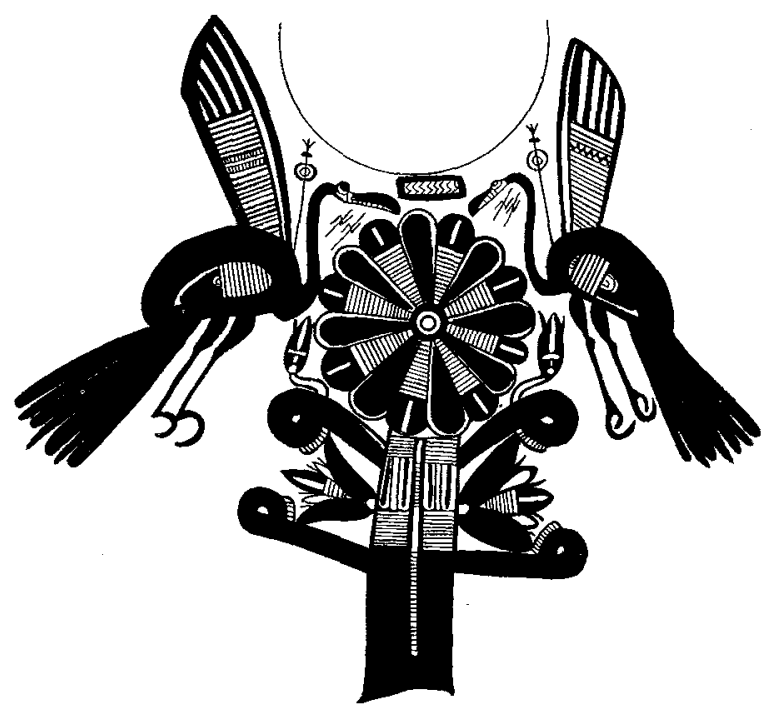

Figura 31: Jarro con árbol sagrado entre aves. Museo del Louvre, Paris. Según V. Karageoghis y J. Cagniers.

chada en torno al 650 a.C., decorada con tres damas desnudas en posición frontal, rodeadas de rosetones, de círculos concéntricos y de aves. M.A. Rizzo (CRISTOFANI Y MARTELLI 1983,284, f. 112), al publicar esta pieza, piensa que las damas pueden ser una deidad de origen fenicio, con prototipos en figuras del II milenio a.C., tesis que encontramos muy probable.

La dama sería Astarté rodeada de sus atributos, como en la pintura vascular ibera. Es la misma diosa desnuda representada varias veces en la corona de estilo sirio, de la segunda mitad del siglo VIII a.C., hoy en la Walters Art Gallery de Baltimore, que E. Akurgal (AKURGAL 1969, 161, 178, f. 42) piensa que se trata de imágenes de una diosa, que debe ser Astarté, pues esta peluca es de origen sirio.

\footnotetext{
${ }^{30}$ MARKOE 1985, 246-247. También se representa esta danza ante una dama sentada (diosa) que bebe un líquido mediante una larga caña sobre el cuerpo de la ánfora Hubbard de la clase Bicroma IV conservada en el Cyprus Museum de Nicosia (KARAGEORGHIS y GAGNIERS 1974, 6-9).

${ }^{31}$ MARKOE 1985, 156, 217-218, 348, U 7. SPITERIS 1970 , 154 fecha entre los años 600-500 a.C., mujeres danzando en círculo alrededor de una figura central, cogidas por la mano. MOSCATI 1972, 50, tres damas desnudas y un varón, alrededor de un cipo de época helenística. El hecho de que los vasos de Liria con procesiones aparecieran en una favissa es una prueba de que las procesiones iberas son de carăcter sagrado (ARANEGUI 1997, 329-343; BLÁZQUEZ 1999a, 305, 319, 363-378).

32 KARAGEORGHIS y GAGNIERS 1974, 2-3. Dos rosetones de ocho pétalos se encuentran a ambos lados de un ave en un jarro de la clase Bicroma IV de la colección Kolokassides en Nicosia (KARAGEORGHIS y GAGNIERS $1974,455)$.
} 


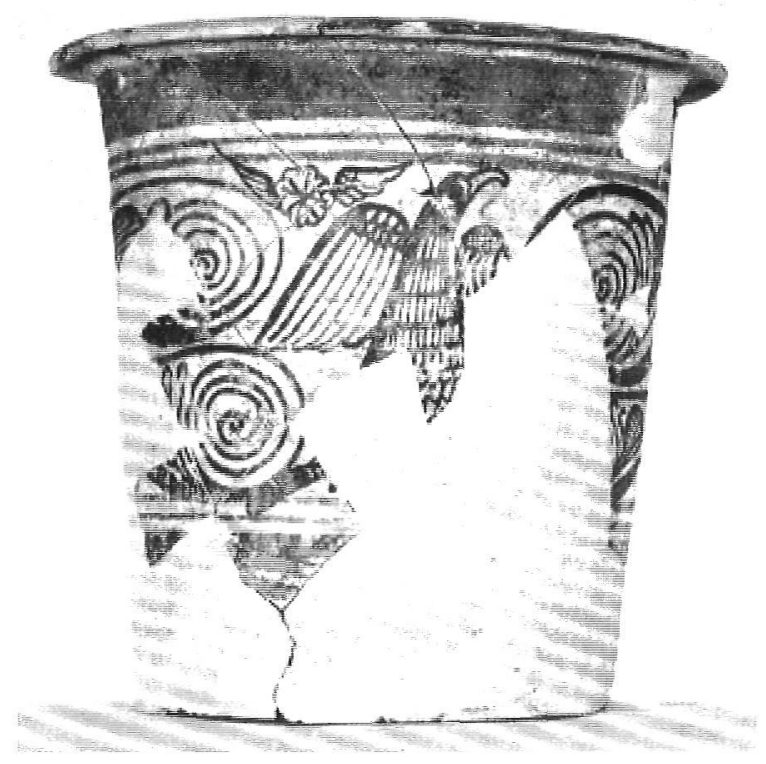

Figura 32: Disco alado. Kalathos de La Alcudia. Según L. Pericot.

\section{Rosetones en la orfebrería griega}

Las joyas griegas van decoradas frecuentemente con rosetones, de cuatro, cinco o más pétalos, como las placas áureas de pectoral de Eleusis (ROCCHETI 1992, 242, f. 47), en torno al 750 a.C., o del British Museum de Londres (ROCCHETI 1992, 250, f. 84); o las citadas placas de pendiente de Camiro con potnia theron con leones; o el mencionado pendiente de Camiro con dama desnuda acompañada de rosetas(ROCCHETI 1992, 242, f. 48); - las rosetas de una cinta áurea de Coo (ROCCHETI 1992, 250, f. 84); o las rosetas decoradas en el interior de otras, halladas en Melo o Milo (ROCCHETI 1992, 250-251, f. 9094), de época orientalizante. En estas últimas piezas las rosetas son de carácter decorativo.

\section{Roseta con alas}

Sobre el cuerpo de una gran tinaja hallada en la Albufereta (Alicante), se pintó un gran pájaro caminando con las alas desplegadas y una roseta con espiral, que posiblemente es una forma estilizada de ala, unida al cuerpo de ave por un vástago, rodeada de plantas (PERICOT 1979, 44-45, ff. 57-58). En una tinaja de La Alcudia de Elche rodeando una gran ave con las alas desplegadas, se encuentran dos rosetas a las que sólo, posiblemente por falta de espacio, se coloca una ala (PERICOT 1979, 103, 105, ff. 128, 130). El carácter sagrado de este símbolo queda bien patente en las pinturas de esta tinaja, pues se representan en ella unas bailarinas sagradas, se ve aún el brazo de otra compañera que se cogían por las manos, rodeadas de los atributos de la diosa, en cuyo honor hacían el ritual, aves, peces, plantas, rosetas y animales que simbolizan que se trata de una diosa de la naturaleza de carácter astral, como era la gran diosa fenicia Astarté o la cartaginesa Tanit. Ya E. Kukahn creía que las diosas aladas de la pintura ibérica eran imágenes de Tanit. Una roseta alada, de tamaño pequeño, se encuentra sobre las alas de una ave en un kalathos de La Alcudia (PERICOT 1979, 81, f. 100) (fig. 32).

Un disco solar alado se representó en la citada copa de Praeneste, en la actualidad en el Museo de Villa Giulia.

El disco alado, símbolo de el sol, contaba con una gran tradición entre las poblaciones del Próximo Oriente. Se encuentra en la estela del dios El de Ugarit (PRITCHARD 1958, f. 138), siglo XIII a.C.; en el ortostato de Sakçegözü encima del rey, protegiéndole en la caza del león (BITTEL, 1976, f. 306). E. Kukahn menciona precisamente este relieve. El disco alado simboliza la potencia divina y humana, así como al sol, añadimos nosotros, puesto que en otros relieves aparece acompañado de la luna.

En el arte hitita y neohitita, el tema es frecuente y antiguo. Baste recordar en el santuario de Yazilikaya al dios sol (BITTEL 1976, ff. 233-234), datado en los años 1250-1220 a.C.; la placa adornada con dos seres híbridos de Alaca-Höyük, siglo XIV a.C. (BITTEL 1976, 246); Tudaliya IV, 1250-1220 a.C. (BITTEL 1976, f. 249; AKURGAL 1962, ff. 76-77), sobre dos montañas del santuario de Yazilikaya; hombre entre dos hombres-toros de Tell Halaf, siglo XIV a.C. (BITTEL 1976, 256); dios de la

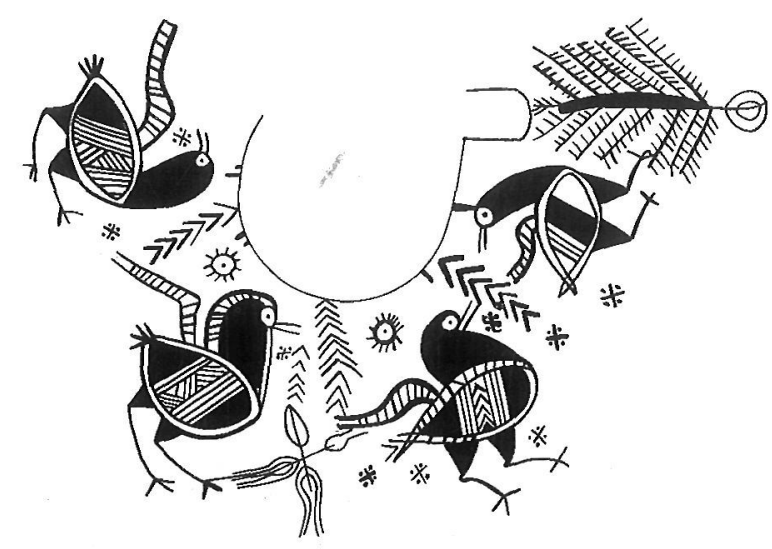

Figura 33: Jarro decorado con aves y motivos florales. Cyprus Museum, Nicosia. Según V. Karageoghis y J. Gagniers. 
tormenta de Basil (AMIET 1980, f, 553); de la estela de Sam'al de estilo arameizante con princesa y esclava, siglo VIII a.C. (AKURGAL 1962, f. 130); el citado relieve de la puerta principal de Sakçegözü; relieve con hombre pájaro de la puerta septentrional de Karatepe, datado en torno al 700 a.C. (AKURGAL 1962, f. 149), etc. También se documenta en marfiles del fuerte de Salmanasar ${ }^{33}$.

Es un símbolo traído por los fenicios a Occidente y que en el Levante ibérico se mantuvo hasta la época helenística. Se encuentra, por primera vez en Occidente, en el siglo VI a.C., en la esfinge de Andujar ${ }^{34}$.

\section{Las rosetas}

La roseta está frecuentemente representada en la cerámica vascular ibérica, no en la pintura ni en la vascular etrusca ${ }^{35}$, ni en la pintura funeraria de Paestum ${ }^{36}$, ni en la vascular de Apulia ${ }^{37}$. Se la encuentra también en el Próximo Oriente, como en el citado relieve de Salçegözü, donde cuatro rosetas están encima del león. Probablemente simbolizan los astros, como en la pátera de Ras Shamra, llena de símbolos religiosos, como el árbol sagrado entre esfinge y toro. En Chipre decora el cielo de las cámaras funerarias quizás como simple elemento decorativo (KARAGEORGHIS 1969, ff. 59-60, 88). Está presente con frecuencia en la pintura vascular chipriota, como en un jarro del periodo Bicroma IV decorado con dos varones y un ave. El varón, colocado en el centro de la escena, se encuentra entre dos rosetas, que V. Karageorghis y J. des Gargniers (KARAGEORGHIS 1969, 42) interpretan como motivo estelar.

En un jarro chipriota de la clase Bicroma IV, el pintor colocó, encima de un ciervo, un motivo solar con círculos concéntricos (KARAGEORGHIS y GAGNIERS 1974, 182). En otra pieza del mismo tipo y periodo, hoy en el Cyprus Museum de Nicosia (KARAGEORGHIS y GAGNIERS 1974, 470-471) (fig. 33), el cuerpo está decorado con cuatro aves. Un motivo "solar" se encuentra sobre el cuello de dos aves. La roseta es un motivo decorativo muy frecuente en ánforas, jarros y copas de la cerámica chipriota.

En una crátera de la clase Bicroma III del Cyprus Museum de Nicosia, detrás de cada ave y debajo del ala se pintó el signo solar, que acompaña a las aves de la cerámica ibérica (KARAGEORGHIS y GAGNIERS 1974, 338339). Estas pinturas son importantes para co- nocer los lejanos motivos que reaparecen en la cerámica ibérica.

En un ánfora de la colección Leno Pierides de Larnaca, el signo solar se halla detrás del cuello del ave (KARAGEORGHIS y GAGNIERS 1974, 343-344). En un jarro de la clase Bicroma IV, conservado al igual que la mayoría de las piezas anteriores en Nicosia, el motivo solar ${ }^{38}$ está delante del pico del ave. En cambio, en un jarro también perteneciente a la misma clase y museo, el ave acompaña a un árbol estilizado y el motivo solar se encuentra a la derecha o a la altura del pico ${ }^{39}$. De gran originalidad es el ave en el jarro de la clase Bicroma IV, hoy en el Museo del Louvre: el ave pica el disco solar (KARAGEORGHIS y GAGNIERS 1974, 437). Una segunda pieza, igualmente de gran novedad, es el motivo astral, formado por un círculo concéntrico rodeado de pequeños pétalos, delante del ave, en un jarro perteneciente al Bicroma IV. Probablemente es el mismo motivo astral que los pintores anteriores expresaban de modo original $y$ en mayor tamaño (KARAGEORGHIS y GAGNIERS 1974, 453). Con mucha frecuencia las

\footnotetext{
${ }^{33}$ MALLOWAN 1966, 485, f. 385. Esta dama tetraptera colocada debajo del disco solar alado, con flores de loto en las manos, es la misma de Pozo Moro, Astarté; MALLOWAN 1966, 494, f. 490; 502, ff. 401, 409, con dama entronizada con flor de loto en las manos, que debe ser la misma diosa Astarté de las citadas ápteras fenicias, aquí debajo del disco solar alado; MALLOWAN 1966, 514, f. 409, disco solar alado, marfiles todos fechados en torno al 730 a.C., con afinidades estilísticas con el noroeste de Siria y el sureste de Anatolia. De particular importancia es una placa de cabecera de caballo con diosa desnuda sosteniendo en alto dos leones, con flores de loto en las manos, debajo del disco solar alado, figura muy probable de Astarté, diosa vinculada con los caballos (Liria y Chipre) (MALLOWAN 1966, 538, $\mathrm{f}$. 458). Una segunda pieza (MALLOWAN 1966, 582, f. 549), el autor cree que representa a Ishtar, piezas fechadas en la primera mitad del siglo VIII a.C. También BARNETT 1975, 202, f. 146.
}

${ }^{34} \mathrm{El}$ disco alado aparece en uno de los anillos giratorios de La Aliseda, en torno al 600 a.C., encima del árbol sagrado flanqueado por grifos entre dos deidades (NICOLINI 1990, 384, lám 85a) y en el medallón de Trayamar, Málaga, entre dos uraei sobre cabezas de serpientes (NICOLINI 1990, 405407, lám105a) de finales del s. VII a.C.

35 STEINGRÄBER 1984; BEAZLEY 1947; MARTINELLI 1987.

${ }^{36}$ ZEVI 1990, 212-221, 244-268. Sólo un rosetón en la tumba femenina Andriuolo 21.

37 TRENDALL 1966; TRENDALL 1974.

${ }^{38}$ KARAGEORGHIS y GAGNIERS 1974, 388. También 422423 con dos motivos solares superpuestos en un jarro.

${ }^{39}$ KARAGEORGHIS y GAGNIERS 1974, 392-403, con dos motivos solares y dos rosetones a ambos lados del ave. Otro ejemplo 420; con disco solar a ambos lados del ave KARAGEORGHIS y GAGNIERS 1974, 470-471. 


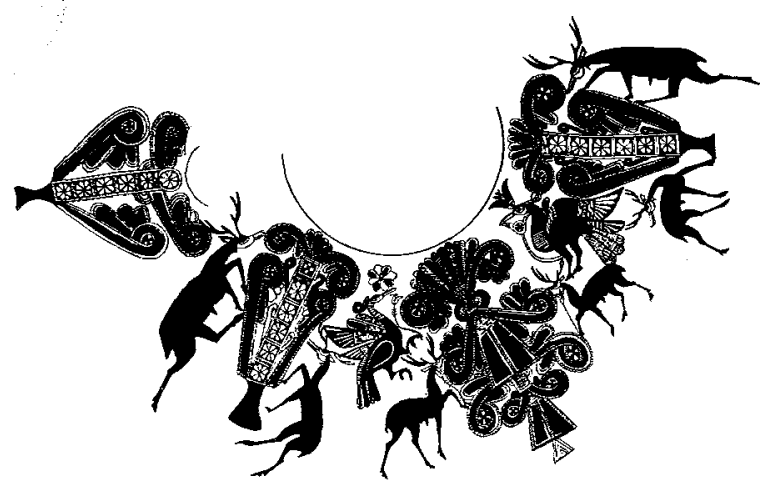

Figura 34: Jarro de la colección Kolokassides. Según V. Karageoghis y J. Gagniers.

aves, en la pintura vascular chipriota, van acompañadas de flores de loto (KARAGEORGHIS y GAGNIERS 1974, 384-391, 393395, 397-408), o de un ramo (KARAGEORGHIS y GAGNIERS 1974, 206-209, 329-331, 358, 362-363, 367-370) (fig. 34), y en la pintura vascular ibera de una gran profusión de vegetales, además de aves, peces y otros animales.

Las rosetas, que acompañan a las diosas, a las aves y al carnicero, son, muy probablemente, símbolos de la diosa Astarté o Tanit en la cerámica ibérica. Ya se han mencionado algunos ejemplos, pero cabe recordar otros más, como la roseta de tamaño relativamente grande, debajo de las fauces de un carnicero, en una tinaja de gran tamaño de La Alcudia (PERICOT 1979, 84, f. 106), o la roseta de una segunda tinaja de la misma procedencia, debajo del carnicero o entre sus fauces y un ave con las alas desplegadas (PERICOT 1979, 85 , f. 107). Una roseta de tamaño grande se encuentra entre las patas traseras de un caballo en una tinaja del mismo yacimiento (PERICOT 1979,90, f. 112). La cultura ibera, como todas las de la Antigüedad, estaba inmersa en lo religioso, como una esponja en el agua. No es extraño encontrar un símbolo religioso, en este caso la roseta, en una escena profana. Al igual que el signo de Tanit en escenas de cacería, como en un vaso de La Alcudia, al igual que la escena de cacería en el relieve de Sakçegözü, el disco solar alado. En una tinaja procedente de la Serreta de Alcoy, entre los pies de un combatiente está representada una roseta, al igual que en una gran copa de San Miguel de Liria. No hay que descartar que estas competiciones tuvieran un carácter sacro.

Estamos de acuerdo con E. Kukahn que las rosetas junto a las aves, son símbolos religiosos en la cerámica de Chipre y el mismo carácter tienen en la cerámica ibérica. Era una manera de pedir la protección divina.

En una gran tinaja hallada en La Alcudia con cinta serpenteante se encuentra detrás del cuello del ave y una segunda entre las patas de una liebre o conejo (PERICOT 1979, 98-99, ff. 124-125). En otra pieza semejante y de la misma procedencia, una roseta está colocada delante de un varón, que se enfrenta con arco a un carnicero. Entre las patas traseras del carnicero hay una segunda roseta (PERICOT 1979, 100-101, f. 126). Aquí las rosetas deben tener cierto sentido apotropaico de protección de la diosa. La lucha contra el carnicero igualmente podía tener carácter religioso, al igual que la lucha contra el león en la mencionada pátera de Ras Shamra, en la que lleva sobre la paletilla el símbolo solar. Tres rosetas rodean la citada bailarina de La Alcudia. En esta tinaja las rosetas, muy probablemente simbolizan a la diosa. Las bailarinas sagradas, de una de ellas sólo se conserva el brazo izquierdo, realizan, como se dijo anteriormente, un ritual a Tanit, rodeadas de otros atributos de la diosa, como peces, aves, animales y vegetales, indicando que es la diosa protectora de toda la naturaleza. En la parte posterior de esta excepcional pieza, en la que se pintaron las dos citadas rosetas con una sola ala, probablemente por falta de espacio, detrás del cuello del ave se colocó otra roseta. Los atributos de la diosa se multiplicaban en una misma composición.

Más importancia, desde el punto de vista del presente trabajo, es la tinaja de La Alcudia, con una imagen de la diosa con las alas desplegadas, con dos rosetones próximos al cuerpo. En todas estas pinturas en que la diosa alada es acompañada por rosetas, queda bien patente el carácter de símbolo religioso de la roseta (PERICOT 1979, 115, f. 150). El atributo unas veces acompaña a la diosa y otras va solo.

\section{Aves}

Uno de los aciertos grandes del trabajo de Kukahn, consistió en Ilamar la atención sobre algunas aves con ciertos motivos decorativos sobre el cuello y sobre las relaciones de este tema de la cerámica ibérica con el Oriente y, concretamente, con Chipre. Es un tipo de aves que es frecuente en la pintura vascular ibera. Baste recordar la gran tinaja de La Albufereta, en la que aparece un ave, con las alas desplegadas, entre motivos vegetales con roseta alada, unida por un vástago al cuello del 
animal. Debajo de una figura de la diosa, colocada de frente, de pie y vestida con larga túnica, acompañada por todo tipo de atributos, aves, animales, pájaros, se encuentra en una jarra de La Alcudia (PERICOT 1979, 73, f. 94). En el citado vaso de forma de embudo, hallado en La Alcudia, con busto de diosa alada debajo del asa, en el lado opuesto se pintó un ave con las alas desplegadas y una roseta alada con vástago que se apoya sobre el cuerpo.

Aves con motivos decorativos sobre el cuello son bien conocidos en la pintura vascular chipriota. Es suficiente mencionar el ave con dos grandes hojas sobre el cuerpo, delante de un hombre, de un jarro de la clase Bicroma IV (KARAGEORGHIS y GAGNIERS 1974, 105); el motivo floral repetido en una copa de la clase Bicroma III del Medelhavsmusee de Estocolmo (KARAGEORGHIS y GAGNIERS $1974,284)$; las dos aves con las alas desplegadas verticales sobre el cuerpo, con tema floral sobre ellas de una copa de la clase Bicroma IV, del Cyprus Museum de Nicosia (KARAGEORGHIS y GAGNIERS 1974, 285); el motivo repetido de un disco entre dos pétalos en el ave pintada de la copa de la clase Bicroma IV del Museo Nacional de Copenhague, donde sobre la cabeza del ave se apoya un vástago, que termina en tres pequeños discos (KARAGEORGHIS y GAGNIERS 1974, 288); el ave con flor de loto sobre la cabeza y hoja entre las alas y el cuello de un jarro de la clase Bicroma IV, decorado con tres motivos, que son posiblemente representaciones del árbol sagrado (KARAGEORGHIS y GAGNIERS 1974, 206207).

Importante, como punto de comparación con algunas aves ibéricas es el ave de un fragmento cerámico de la clase Bicroma IV, con disco solar sobre vástago, que se apoya en los hombros del ave; aquí se tendría, posiblemente, el tema de la roseta unida al ave de la cerámica ibérica (KARAGEORGHIS y GAGNIERS 1974, 309). En el mencionado jarro del Museo del Louvre, con grandes pájaros alrededor del árbol sagrado, rematado en un gran rosetón sobre los hombros de las dos aves, se repite un motivo floral estilizado. En una crátera de la clase Bicroma IV, hoy en el Cyprus Museum de Nicosia, un botón de loto parte del hombro de tres aves (KARAGEORGHIS y GAGNIERS 1974, 310-311) (fig. 35), estos motivos decorativos se documentan por igual en las cerámicas chipriotas e iberas. Los ejemplos se podían multiplicar ${ }^{40}$. Una de las piezas más bellas es el ave ante flor de loto, con otra flor

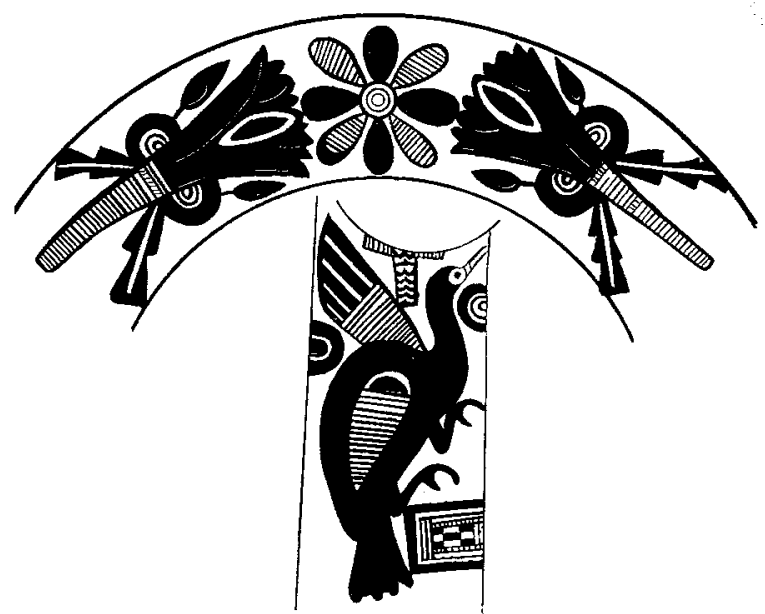

Figura 35: Crátera decorada con filas de aves y rosetas. Cyprus Museum, Nicosia. Según V. Karageoghis y J. Gagniers.

entre el cuello y el ala del jarro de la clase Bicroma IV de la colección Hadjiprodomou ${ }^{41}$.

\section{Diosas}

En la pintura vascular ibérica se representan las diosas mencionadas con anterioridad, de cuerpo entero, en La Alcudia aladas y entronizadas en San Miguel de Liria., ante el árbol sagrado (BLÁZQUEZ 1999b, 79, f. 18), o llevada en andas (BLÁZQUEZ 1999b, 79, f. 18), como las diosas del Oriente (PRITCHARD 1958 , f. 145), o entronizadas entre músicos como en la Serreta de Alcoy (BLÁZQUEZ 1999b, 76-77, f. 16). R. Ramos se inclina a pensar que la iconografía de esta diosa alada solamente está influenciada por lo griego en lo referente a la expresión plástica de su representación. Piensa el autor que "esta divinidad está presente en Elche desde época arcaica, por lo que la única innovación de la época helenística consistió en aplicar a la cerámica una temática decorativa que en el mundo ibérico, hasta entonces, sólo se había plasmado en modelos escultóricos", lo que es muy probable.

${ }^{40}$ KARAGEORGHIS y GAGNIERS 1974, 137, flor de loto; 328-330, círculos concéntricos; 358-359, hojas, etc.

${ }^{41}$ KARAGEORGHIS y GAGNIERS 1974, 407. El tema se repite en un jarro del Ashmolean Museum de Oxford (KARAGEORGHIS y GAGNIERS 1974, 360), en otro del Nicholson Museum de Sydney (KARAGEORGHIS y GAGNIERS 1974, 398) y en un jarro de la colección Hdjiprodomou de Famagusta (KARAGEORGHIS y GAGNIERS 1974, 407, 417, otras piezas: 422, 430-431, 447$449,452-453)$. 


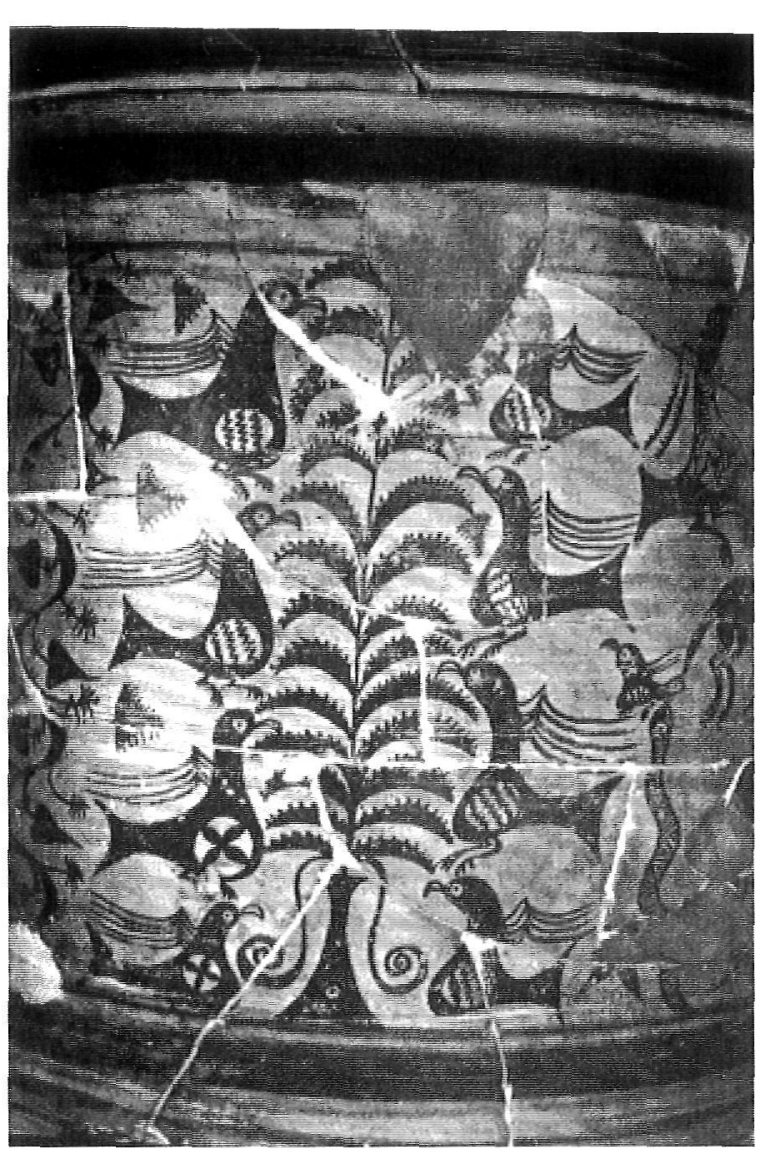

Figura 36: Árbol sagrado. Azaila. Según A. García y Bellido.

Entre los fenicios del Oriente, las representaciones de diosas eran frecuentes. Baste recordar las ya citadas cabezas con peinado de Hator de Chipre; la mencionada ánfora Hubband; la ánfora de Ormidhia (KARAGEORGHIS y GAGNIERS 1974, 10-11); las ya citadas diosas entronizadas de las páteras fenicias de Idalion, de Esparta, del Iran Bastan Museum de Teherán, de Olimpia, hoy en el Museo Arqueológico Nacional de Atenas (MARKOE 1985, 316-317, 319 G3), datada entre los años 750-700 a.C. Las damas entronizadas de los marfiles de Nimrud, con flores de loto en sus manos, con esfinges debajo del trono, son muy probablemente imágenes de Astarté (MALLOWAN 1966, 500, f.199; 502, f. 404). Astarté entronizada entre esfinge, obra siria de mediados del siglo VIII a.C., es la diosa de Galera (BLÁZQUEZ 1999b, 58, f. 5) y sigue un modelo que se repite en Palermo, frecuente en gemas fenicias.

Las diosas entronizadas de las páteras fenicias, igual que las dos damas afrontadas de la citada ánfora Ormidhia y el relieve de Pozo Moro, con la diosa Astarté sentada con seis alas y con flores de loto en las manos ${ }^{42}$ son imágenes de Astarté.

\section{Árbol sagrado}

En la pintura chipriota se representa con frecuencia un árbol, que suponemos sagrado, rodeado de aves, cabras o ciervos. Se acaba de mencionar a una diosa entronizada de San Miguel de Liria delante de un árbol sagrado. El tema del árbol sagrado rodeado de aves se repite en la pintura de Azaila (GARCÍA Y BELLIDO 1963, 660, ff. 921-922) (fig. 36). Un paralelo para esta composición es el árbol terminado en flor de loto, rodeado de dos aves, del jarro de la clase Bicroma IV, de Cyprus Museum de Nicosia (KARAGEORGHIS y GAGNIERS 1974, 374-375) (fig. 37).

Hace muchos años, 1914, un gran conocedor del periodo orientalizante, F. Poulsen (POULSEN 1912, passim) señaló que en la pintura de Azaila (PERICOT 1979, 231, f. 372; 237, f. $379 ; 239$, f. $381,240-241$, ff. 383-384) había representaciones muy esquematizadas del árbol de la vida, con el esquematismo propio del arte celta ${ }^{43}$, añadimos nosotros.

La península ibérica es una zona marginal, como Tracia (VENEDIKOU y GERASSINOU, 1973) y los modelos recibidos se mantienen durante muchos siglos. En el levante ibérico hubo desde la antigüedad importantes

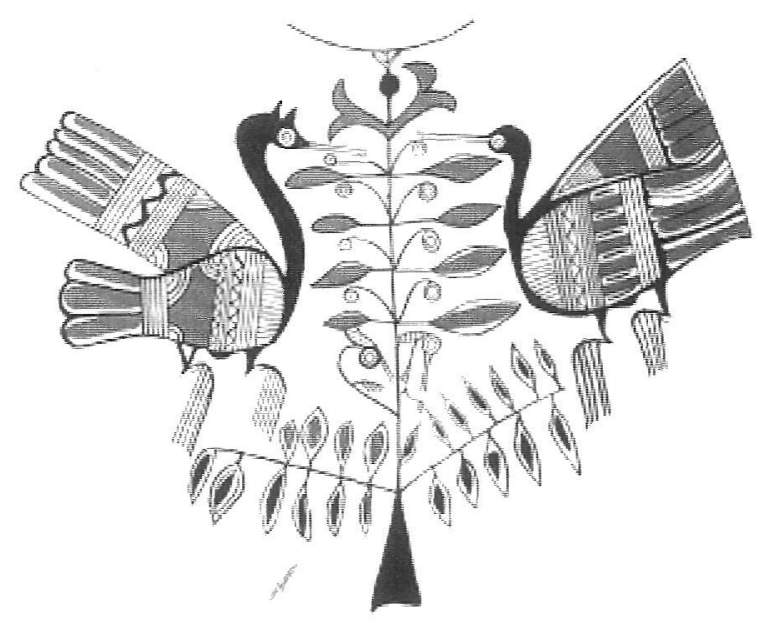

Figura 37: Jarro con árbol sagrado entre aves. Cyprus Museum, Nicosia. Según V. Karageorghis y J. Gagniers.

${ }^{42}$ BLÁZQUEZ 1999b, 60, f. 7. En dos anillos de La Aliseda, que proceden de Oriente (BLANCO 1996, 79, 83, ff. 59, 61), hay volutas superpuestas que simbolizan probablemente el árbol de la vida, con paralelos en marfiles de Nimrud (MALLOWAN 1966, 510, ff. 414-415). Véase también NICOLINI 1990, 263-264, f. 84b-c.

${ }^{43}$ JACOBSTHAL 1969; MOSCATI 1991. 
asentamientos fenicios, como La Fonteta ${ }^{44}$. Estos prototipos llegaron muy a comienzos de la colonización fenicia.

E. Kukahn en su fundamental trabajo sobre los símbolos de la Gran Diosa en la pintura vascular ibérica, se planteó el problema de si todos estos símbolos eran recibidos del Mediterráneo oriental o eran indígenas. El profesor de Bonn no descartaba una evolución indígena. Nos inclinamos a sostener que los símbolos, solos o acompañados de la diosa, se debían a influjos exteriores. Estos símbolos tienen una gran tradición en el Mediterráneo y en el Próximo Oriente, principalmente en el periodo orientalizante, cuando los fenicios los propagaron por Grecia, Etruria e Iberia, aquí pervivieron muchos siglos.

$V$. Karageorghis no cree que haya influjo chipriota en Occidente, teoría contraria a la nuestra ${ }^{45}$. Nosotros hemos insistido también en un componente sirio y arameo en la colonización fenicia en occidente ${ }^{46}$, que explica Pozo Moro, con sus relieves planos y los mitos de Cronos devorando a sus hijos, mito que se lee en la Historia Fenicia de Filón de Biblos (siglo 11) que se remonta a Sanjuniatón, que vivió en la época de la guerra de Troya, extractado en la Praeparatio Evangelica de Eusebio de Cesarea (siglo IV), y las leyendas de Gilgamesh talando los cedros del Líbano y Enkidu y la ramera sagrada.

En la actualidad nos inclinamos a aceptar que las telas orientales, en cuya confección eran tan hábiles los fenicios, pudieron desempeñar un papel importante. En la más antigua cerámica pintada de Cástulo, los temas están copiados de telas.

Estamos de acuerdo con el pensamiento de E. Kukahn de que toda la pintura ibérica, según indicamos ya, está llena de simbología religiosa, que no es ornamental sólo. E. Kukahn, apoyado en los paralelos entre la cerámica oriental y la del levante ibero, es partidario de levantar la cronología de esta última, que creemos ya de época helenística.

\section{BIBLIOGRAFÍA}

AAVV s/a: Tartessos. 25 años después. 1968-1993, Jerez de la Frontera.

AAVV 1986: Tartessos. Revista de Arqueología, Madrid. AAVV 2000: Argantonio. Rey de Tartessos, Valencia

AKURGAL, E. 1962: L'Arte degli ittiti, Florencia.

AKURGAL, E. 1969: Orient et Occident. La naisance de l'art grec, París.

ALMAGRO BASCH, M. 1999: El rey lobo de La Alcudia de Elche, Alicante.
ALMAGRo GorBeA, M. 1980: Corpus de terracotas de Ibiza, Madrid.

ALVAR, J. Y BLÁZQUEZ, J.M. 1993: Los enigmas de Tartessos, Madrid.

AMIET, P. 1980: Art of the Ancient Near East, Nueva York

ARANEGUI, C. 1997: "La favissa del santuario de EdetaLuna (Valencia)", Quad. Preh. Cast. 18, 329-343.

AUBET, M.E. 1976: “Algunos aspectos sobre iconografía púnica: las representaciones de Tanit", Homenaje a García y Bellido 1, 61-82.

AUBET, M.E. 1985: Tartessos. Arqueología protohistoria del Bajo Guadalquivir, Sabadell.

AUBET, M.E. 1994: Tiro y las colonias fenicias en Occidente, Barcelona.

BANDERA, M.L. de la 1994: "Arracada siriana en Cástulo (Linares, Jaén)", El Mundo Mediterráneo siglos IIIVII. Actas del III Congreso Andaluz de Estudios Clásicos, Madrid, 265-273.

BANDERA, M.L. de la 1998: "Arracada orientalizante de Villanueva de la Vera (Cáceres). Propuesta de reconstrucción", SPAL 7, 107-127.

BARNETT, N.D. 1975: A Catalogue of the Nimrud Ivories, Londres.

BEAZLEY, J.D. 1947: Etruscan vase-painting, Oxford.

BELÉN, M. y otros 1998: Arqueologia de Carmona (Sevi11a). Excavaciones en la Casa-Palacio del Marques de Saltillo, Sevilla.

BITTEL, K. 1976: Los Hititas, Madrid.

BLANCO, A. 1988: “Escultura ibérica», Revista Arqueología, Madrid, 32-48.

BLANCO, A. 1993: «El carnassier de Elche», Homenaje a Alejandro Ramos Folqués, Elche, 86-97.

BLANCO, A. 1996: "Antonio Blanco Freijeiro. Opera minora selecta», LUZÓN, J.M. y LEÓN, P. (eds), Sevilla

BLANCO, A. G., CUNCHILLOS, J.L. y MOLINA, M. (eds) 1994: El mundo púnico. Historia, sociedad y cultura, Murcia.

BLÁZQUEZ, J.M. 1975a: Diccionario de las religiones prerromanas de Hispania, Madrid.

BLÁZQUEZ, J.M. 1975b: Tartessos y los orígenes de la colonización fenicia en Occidente, Salamanca.

BLÁZQUEZ, J.M. 1980: Historia de España. I. Protohistoria, Madrid.

BLÁZQUEZ, J.M. 1982: Primitivas religiones ibéricas II. Religiones prerromanas, Madrid.

BLÁZQUEZ, J.M. 1988: Historia del arte hispánico. I. La Antigüedad, Madrid.

BLÁZQUEZ, J.M. 1989: Tartessos. Historia de España. 2 Colonizaciones y formación de los pueblos prerromanos (1200-218 a.C.), Madrid.

BLÁZQUEZ, J.M. 1991: Urbanismo y sociedad en Hispania, Madrid.

BLÁZQUEZ, J.M. 1993a: Fenicios, griegos y cartagineses en Occidente, Madrid.

BLÁZQUEZ, J.M. 1993b: "Sirios y arameos en la colonización fenicia en Occidente", RSF, XXI.

BLÁZQUEZ, J.M. 1997: "Astarté, señola de los caballos en la Hispania prerromana», SRS XXV, 79-95.

${ }^{44}$ GONZÁLEZ PRATZ 1996, 8-13. Ya el autor (GONZÁLEZ PRATZ 1983) al estudiar el poblamiento antiguo de la Sierra de Crevillente señaló importantes relaciones con el sur de España en el periodo orientalizante. Baste recordar la placa decorada con palmetas de cuenco de cepillo. GONZÁLEZ PRATZ 1998, 191-228; ELAYI, GONZÁLEZ PRATZ y RUIZ SEGURA 1998, 229-242; GONZÁLEZ PRATZ y RUIZ SEGURA 2000; NICOLINI 1990, 494-495, lám 163a-d.

${ }^{45}$ BLÁZQUEZ 1998, 595-603; BLÁZQUEZ 2000, 94-103.

${ }^{46}$ BLÁZQUEZ 1993a, 280-288; BLÁZQUEZ 1993, 41, 52; BLÁZQUEZ 1999a, 129-146; BANDERA 1994, 265-273; BANDERA 1998, 107-127. 
BLÁZQUEZ, J.M. 1998: «La península ibérica y Chipre antes de los romanos", Vörff Joaquim Tunguis Ges. Wiss. Hamburg 87.

BLÁZQUEZ, J.M. 1999a: Mitos, dioses y héroes en el Mediterráneo Antiguo, Madrid.

BLÁZQUEZ, J.M. 1999b: «El impacto de la religión semita, fenicios y cartagineses e la religión ibera", Curso de Verano UIMP, Valencia, 1-35.

BLÁZQUEZ, J.M., ALVAR, y J. WAGNER, C.G. 1999: Fenicios y cartagineses en el Mediterráneo, Madrid.

BLÁZQUEZ, J.M. y VALIENTE, J. 1981: Cástulo III, Madrid.

BLÁZQUEZ, J.M., GARCÍA-GELABERT y LÓPEZ PARDO, F. 1985: Cástulo V, Madrid.

CRISTOFANI, M. y MARTELLI, M. 1983: L'oro degli etruschi, Novara.

CORZO, R. 1989: Historia del arte en Andalucia. La Antigüedad, Sevilla.

DEL OLMO LETE, G. y AUBET, M.E. (eds) 1986: Los fenicios en la Península lbérica, Sabadell.

DUNBABIN, K.M.D. 1957: The Greeks and their Eastern Neighbours, Londres.

ELAYI, J., GONZÁLEZ PRATZ, A. y RUIZ SEGURA, E. 1998: «Una lampe avec inspiration phénicienne de La Fonteta (Guardamar, Alicante", RSF, XVI.

FRANKFORT, H. 1970: Arte e architettura dell'Antico Oriente, Turín.

GARCÍA Y BELLIDO, A. 1963: Arte ibero. Historia de España. España prerromana, Madrid.

GONZÁLEZ PARTZ, A. 1983: Estudio arqueológico del poblamiento antiguo de la Sierra de Crevillente (Alicante), Alicante.

GONZÁLEZ PRATZ, A. 1991: "La presencia fenicia en el Levante peninsular y su influencia en las comunidades indígenas", I-IV Jornadas de Arqueologia Fenicio-Púnica 1986-1989, Ibiza, 109-118.

GONZÁLEZ PRATZ, A. 1996: «La Fonteta. Una ciudad fenicia en Occidente», Revista Arqueología, 190.

GONZÁLEZ PRATZ, A. 1998: «La Fonteta. El asentamiento fenicio de la desembocadura del río Segura. Guardamar, Alicante, España. Resultados de las excavaciones de 1996-1997", RSF, XXVI.

GONZÁLEZ PRATZ, A. y RUIZ SEGURA, E. 2000: El yacimiento fenicio de La Fonteta (Guardamar del Segura, Alicante, Comunidad Valenciana), Valencia.

GONZÁLEZ, J. 1997: "Simbología de la diosa Tanit en representaciones cerámicas ibéricas», Quad. Preh. Arq. Cast. 18, 329-343.

GUADÁN, A.M. de 1980: La moneda ibérica, Madrid.

HERZOG, Ch. y GICHON, M. 1997: Battles of the Bibla, Londres.

HUSS, W. 1993: Los cartagineses, Madrid.

JACOBSTHAL, P. 1969: Early celtic art, Oxtord.

KARAGEORGHIS, V. 1969: Salamis in Cyprus. Homeric, Hellenistic and Roman, Londres.

KARAGEORGHIS, V. 1981: Ancient Cyprus. 7000 years of art and archaeology, Londres.

KARAGEORGHIS, V. y GAGNIERS J. des 1974: La cerámique chypriote de style figuré. Âge du Fer (1050500 av. J.C.), Roma.

KRINGS, V. 1995: La civilisation phénicienne et punique, Leiden.

KUKAHN, E. 1962: "Los símbolos de la gran diosa en la pintura de los vasos ibéricos levantinos", Caesaraugusta 19-20, 79-85.

LÓPEZ CASTRO, J.L. 1995: Hispania Poena. Los fenicios en la hispania romana, Barcelona.

MALLOWAN, M.E.L. 1966: Nimrud and its Remain, Londres.

MALUQUER, J. (ed) 1969: Tartessos. V Symposium Internacional de Prehistoria Peninsular, Barcelona.

MARKOE, GI. 1985: Phoenician Bronze and Silver Bowls from Cyprus and the Mediterranean, Berkeley.

MATA, M. 1995: «Las influencias del mundo fenicio-púnico en los orígenes y desarrollo de la cultura ibérica",
III Congrés Internationale des Etudes Phéniciennes et Puniques (Tunis 1991), Túnez, 225-244.

MARÍN CEBALLO, M.C. 1987: “¿Tanit en España?", Lucentum VI, 43-79.

MARTINELLI, M. (ed) 1987: La cerámica degli etruschi. La pittura vascolare, Novara.

MARTIN RUIZ, J.A. 1995: Los fenicios en Andalucía, Sevilla.

MAURI, A. 1963: La peinture romaine, Ginebra.

MOSCATI, S. 1972: I Fenici e Cartagine, Turín.

MOSCATI, S. (ed) 1988: I Fenici, Milán.

MOSCATI, S. (coord) 1991: / Celti, Milán.

NICOLINI, G. 1990: Tecniques des Ors Antiques. La bijouterie ibérique du VIle ai IVe siècle, París.

NIEMEYER, E.G. (ed) 1982: Phoenizier im Western, Maguncia.

NUNNEZ GALIANO, M.P. 1985: «El pebetero de Guadalhorce: Tanit», Jálega, 3-6.

OLIVER, A. 1995: «La presencia púnica en los asentamientos ibéricos: una aproximación a su probelmática", III Congrés Internationale des Etudes Phéniciennes et Puniques (Tunis 1991), Túnez, 282-296.

OLMOS, R. 1988-89: «Originalidad y estímulos mediterráneos en la cerámica ibérica: el ejemplo de Elche", Lucentum VII-VIII, 79-102.

PENA, M.J. 1984: «Los thymiateria en forma de cabeza femenina hallados en el Noroeste de la Península lbérica", Revue des Etudes Anciennes 89, 349-358.

PENA, M.J. 1987: «Consideración sulla diffusione nel Mediterráneo occidentale del brucia profumi a forma di testa femminile», Atti del // Congreso Internazionale di Studi Fenici e Punici, Roma, vol III, 1109-1118.

PENA, M.J. 1990: «Consideraciones sobre la iconografía mediterránea: los pebeteros en forma de cabeza", $L a$ Mediterrània, Antropología i Historia. VII Jornades d'Estudis Historics, Palma, 55-66.

PERICOT, L. 1979: Cerámica lbérica, Barcelona.

POVEDA, A.M. 1997: «Melqart y Astarté en el Occidente Mediterráneo: evidencia de la Península Ibérica (siglos VIII-VI a.C.)", De Oriente A Occidente. Los dioses fenicios en las colonias occidentales. XII Jornadas de Arqueología fenicia (Eivissa 1997), Ibiza.

POULSEN, F. 1912: Der Orient und die frühgriechische Kunst, Leipzig-Berlín.

PRITCHARD J.B. 1958: The Ancient Near East I. An Antology of Tetxt and Pictures, Princeton.

RAMOS, R. 1988: «La escultura antropomorfa de Elche», Revista de Arqueologia, Madrid, 96-97.

RAMOS, R. 1991: Simbología de la cerámica ibérica de La Alcudia de Elche, Elche.

RAMOS, R. 1994: "Sobre dos fragmentos ibéricos de La Alcudia decorados con rostros frontales", Lucentum XI-XIII, 127-130

REMESAL, J. 1975: "Cerámicas orientalizantes andaluzas», AEspA, 48, 3-7.

ROCCHETI, L. 1992: L'oro dei greci, Novara.

RUIZ MATA, D., SCHUBART, H. y ARTEAGA, O. 1994: Historia de España. I. Desde la prehistoria hasta la conquista romana (siglo III a.C.), Barcelona.

SPITERIS, T. 1970: Art de Chipre des origines à l'époque romaine, París.

STEINGRÄBER, ST. 1984: Catalogo ragionato della pittura etrusca, Milán.

TRENDALL, A.D: 1966: South Italian Vase Painting, Londres.

TRENDALL, A.D. 1974: Early South Italian vase painting, Maguncia.

VENEDIKOU, I. y GERASSINOU, T. 1973: Thrakische Kunst, Viena.

WAGNER, C.G. 1983: Fenicios y cartagineses en la Península lbérica. Ensayo de interpretación fundado en un análisis de los factores internos, Madrid.

ZEVI, F. 1990: Paestum, Nápoles. 